\title{
FOOD RESOURCE UTILIZATION OF THE SKATES Rioraja agassizii (MÜLLER \& HENLE, 1841) AND Psammobatis extenta (GARMAN, 1913) ON THE CONTINENTAL SHELF OFF UBATUBA, SOUTH-EASTERN BRAZIL
}

\author{
MUTO, E. Y., ${ }^{1}$ SOARES, L. S. H. ${ }^{1}$ and GOITEIN, R. ${ }^{2}$ \\ ${ }^{1}$ Departamento de Oceanografia Biológica, Instituto Oceanográfico, Universidade de São Paulo, C.P. 66149, \\ CEP 05389-970, São Paulo, SP, Brazil \\ ${ }^{2}$ Departamento de Zoologia, Instituto de Biociências, Universidade Estadual Paulista, C.P. 199, CEP 13506-900, \\ Rio Claro, SP, Brazil \\ Correspondence to: Elizabeti Yuriko Muto, Departamento de Oceanografia Biológica, Instituto Oceanográfico, \\ Universidade de São Paulo, C.P. 66149, CEP 05389-970, São Paulo, SP, Brazil, e-mail: mutokika@usp.br \\ Received December 22, 1999 - Accepted April 24, 2000 - Distributed May 31, 2001
}

(With 12 figures)

\begin{abstract}
The feeding habits of Rioraja agassizii (syn. Raja agassizii) and Psammobatis extenta (syn. Psammobatis glansdissimilis) of the South-eastern Brazilian coast were studied by means of stomach content analysis. The samples were obtained on eight seasonal oceanographic cruises, carried out between October 1985 and July 1987. The importance of each food item was evaluated on the basis of the Index of Relative Importance and the feeding similarity by Percentage of Similarity. The results indicated that both species are benthic feeders, preying mainly on Crustacea, especially Amphipoda, Caridea and Brachyura. Teleostei were also important for $R$. agassizii. Seasonal variation of the diet seems to be associated with the availability of the prey, whose distribution and abundance are related to the dynamics of the water masses of the region. Juveniles and adults of $P$. extenta exploited the same resources while juveniles and adults of $R$. agassizii presented low diet similarity during most of the year. Caridea were an important food for all length classes of $R$. agassizii, while Amphipoda were for smaller specimens, and Teleostei for larger ones. The feeding overlap between the two species was higher during autumn 1986, winter 1986 and winter 1987.
\end{abstract}

Key words: Rajidae, stomach content, feeding habits, South Atlantic, Brazil.

\section{RESUMO}

Utilização dos recursos alimentares pelas raias Rioraja agassizii (Müller \& Henle, 1841) e Psammobatis extenta (Garman, 1913) na plataforma continental de Ubatuba, sudeste do Brasil

Os hábitos alimentares de Rioraja agassizii e Psammobatis extenta da região costeira de Ubatuba, SP, foram investigados por meio da análise de conteúdos estomacais. As amostras foram obtidas em oito campanhas oceanográficas sazonais realizadas no período de outubro de 1985 a julho de 1987. A importância do item alimentar foi avaliada pelo Índice de Importância Relativa e a sobreposição alimentar pela Porcentagem de Similaridade. As duas espécies se alimentaram de organismos bentônicos, principalmente crustáceos. Os Amphipoda, os camarões Caridea e os Brachyura foram as presas mais importantes. Além dessas presas, Teleostei foi importante na dieta de R. agassizii. A variação sazonal da alimentação das raias esteve associada à disponibilidade de suas presas, cuja distribuição e abundância estão relacionadas às variações sazonais das condições oceanográficas da região. A alimentação de jovens e adultos de $P$. extenta foi muito semelhante, enquanto jovens e adultos de $R$. agassizii apresentaram baixa similaridade alimentar na maioria das estações do ano. Caridea foi importante para todos os 
tamanhos de R. agassizii, Amphipoda para exemplares menores e Teleostei para indivíduos maiores. A sobreposição alimentar entre as duas espécies foi alta no outono de 1986 e nos invernos de 1986 e 1987.

Palavras-chave: Rajidae, conteúdo estomacal, hábitos alimentares, Atlântico Sul, Brasil.

\section{INTRODUCTION}

Studies of feeding habits are essential to the understanding of the functional role of fish within the ecosystem. Nikolsky (1963) has already pointed out the importance of understanding how fish exploit food resources and their interaction with other predators, in order to develop a rational method of commercial stock exploitation. In the last ten years, the importance in using food data in multispecific system models has been emphasized by many authors (Livingston et al., 1986; Greenstreet, 1995). Although some species have no fishery interest, information about their feeding is helpful in assessing fishery stocks, since they may be potential competitors or predators of commercially important species, thus interfering in their mortality rate.

The demersal community of the continental platform of Ubatuba, their relationship with the environment and some aspects of the life cycle of the most abundant fish species have been investigated within the multidisciplinary research project "Rational Utilization of Coastal Ecosystems of the Brazilian Tropical Region", carried out by the Instituto Oceanográfico (Universidade de São Paulo). In the region between the coast and the $50 \mathrm{~m}$ isobath, 111 species of demersal fish have been identified (Rocha \& Rossi-Wongtschowski, 1998). The skates Rioraja agassizii and Psammobatis extenta are very important in this system, in terms of abundance and biomass. Both species are endemic to the Argentinean Marine Zoogeographical Province, which comprises the region between "Cabo Frio" (Brazil) and "Península Valdés" (Argentina) (Figueiredo, 1981). Recent phylogenetic analysis of skates have raised Rioraja to generic status (McEachran \& Dunn, 1998), Rioraja agassizii (Müller \& Henle, 1841) being synonymous with Raja agassizii. Psammobatis extenta (Garman, 1913 ) is a senior synonym of Psammobatis glansdissimilis McEachran, 1983 (Carvalho \& Figueiredo, 1994).
Studies on the diet of Brazilian skates are very few (Bacescu \& Queiroz, 1985; Pires, 1987; Gouvêia \& Queiroz, 1988; Soares et al., 1992) and some of them focus on specific taxonomic groups of prey.

The aim of this study is the analysis of the food resource utilization of $R$. agassizii and $P$. extenta and detect dietary changes, taking into account abiotic (seasonal) and biotic (sex, life cycle and length of the skates) variables.

\section{Study area}

The area under study is located on the con-

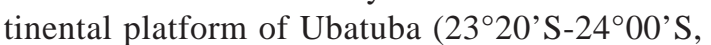

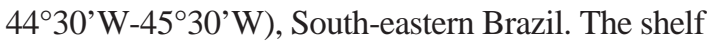
can be divided in two different areas, in accordance with its oceanographic features. The inner domain, where the dynamics is controlled by the wind, is limited by the coast and the 40-50 m isobath. The outer domain extends from this isobath to the shelf break, and is influenced not only by the wind but also suffers the direct influence of the Brazil Current (Castro Filho et al., 1987).

Three water masses occur in the region: the South Atlantic Coastal Water (SACW) with low temperatures $\left(13^{\circ} \mathrm{C}\right)$ and salinity (35.4), Tropical Water (TW) with high temperatures $\left(24^{\circ} \mathrm{C}\right)$ and salinity (37.0) and Coastal Water (CW) related to high temperatures $\left(24^{\circ} \mathrm{C}\right)$ and low salinity (34.9). The seasonal pattern of the dynamics of these water masses provides distinct thermohaline conditions in the summer and winter.

During the summer, the inner domain presents stratification of the water column, with the development of a thermocline. In this season, the upper layer (less than $20 \mathrm{~m}$ in depth) of the region is basically occupied by the $\mathrm{CW}$, which mixes with TW offshore, while the SACW predominates on the bottom, mixing with $\mathrm{CW}$ just near the coast. During winter, when the SACW moves offshore, the inner shelf is occupied by the $\mathrm{CW}$ and the thermocline disappears. 


\section{MATERIAL AND METHODS}

\section{Sampling and laboratory procedure}

The samples were collected at nine sites located from the coast line to the $50 \mathrm{~m}$ isobath (Fig. 1). A total of eight seasonal cruises were made on R/B Veliger II, between October, 1985 and July, 1987. Sampling was carried out by means of a 16.5 $\mathrm{m}$ otter trawl bottom net of $40 \mathrm{~mm}$ stretch mesh in the body and sleeve and $25 \mathrm{~mm}$ in the cod mesh. One-hour hauls at a speed of 2 knots were carried out at the nine sites, during daylight. On board, the fish were sorted and stored in ice. Bottom water temperature and samples for salinity and oxygen estimation were obtained at each site (Fig. 1).

At the laboratory, data on total mass (nearest 0.1 $\mathrm{g})$, total length $(\mathrm{mm})$ and sex were recorded for each specimen. The skates were measured from the tip of the snout to the end of the tail. Specimens were classified as juveniles and adults according to the length at first maturity, which is $330 \mathrm{~mm}$ for $R$. agassizii and 220 $\mathrm{mm}$ for P. extenta (Ponz Louro, pers. comm.). The stomachs were collected and preserved in $10 \%$ buffered formalin solution. The degree of stomach fullness was recorded on a five level scale, ranging from empty stomach to full stomach (> 75\%) with three intermediate levels: almost empty (> $0 \%$ to $25 \%$ ), half full (> 25\% to $50 \%$ ) and almost full (> 50\% to $75 \%$ ). Stomach contents were sorted and the food items were identified to the lowest possible taxonomic level. For each prey group, occurrence, number and wet mass (nearest $0.001 \mathrm{~g}$ ) were recorded.

\section{Data analysis}

The length distribution frequency of the skates was calculated, taking into account length classes of $50 \mathrm{~mm}$ and $20 \mathrm{~mm}$ for $R$. agassizii and $P$. extenta, respectively.

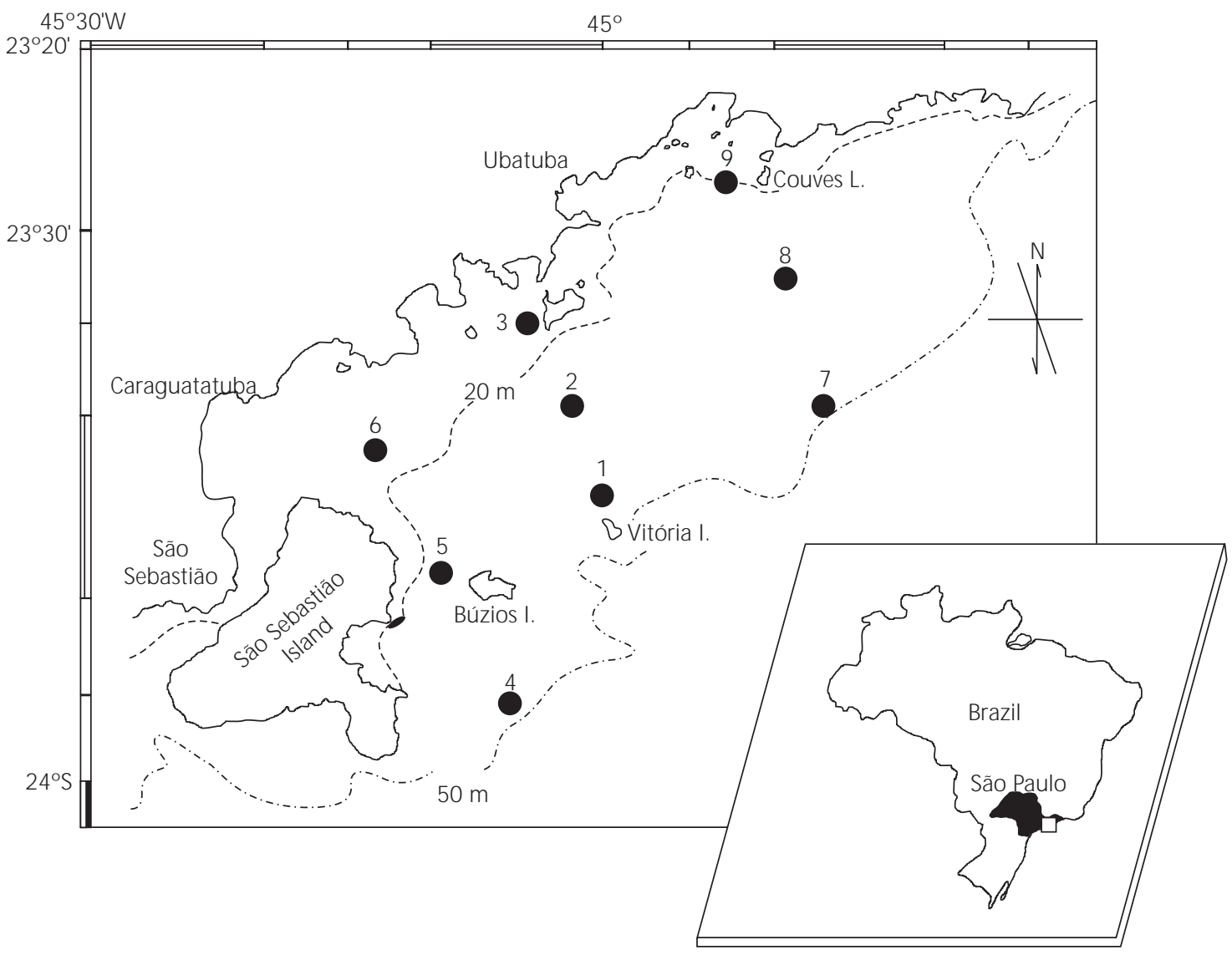

Fig. 1 - Map of the area showing the sampling sites. 
Diet composition was analyzed by the relative frequency of occurrence, number and mass (Berg, 1979; Hyslop, 1980). The Index of Relative Importance (IRI) was calculated for the major prey categories (Pinkas et al., 1971) as: IRI $=(\% \mathrm{~N}+\%$ $\mathrm{M}) \% \mathrm{~F}$, where $\mathrm{N}$ is number, $\mathrm{M}$ is mass and $\mathrm{F}$ is the occurrence of prey in the stomach contents. In order to compare the samples, IRI values were transformed into percentages. Although nematods occurred frequently in the stomachs, this group was not considered as a prey item, since they are regarded as parasites. Data on prey mass by season are presented in Appendixes 1 and 2, due to their importance for trophic modelling.

Aiming at detecting inter and intraspecific dietary overlap, the Shoener's index (Linton et al., 1981) was used: $\mathbf{P S}=\mathbf{1 0 0}-\mathbf{0 . 5} \Sigma\left|\mathbf{P}_{\mathrm{xi}}-\mathbf{P}_{\mathrm{yi}}\right|$ where PS is Percentage of Similarity, $\mathrm{P}_{\mathrm{xi}}$ and $\mathrm{P}_{\mathrm{yi}}$ are the proportion of a particular prey group $\mathrm{i}$ in the diet of predators $\mathbf{x}$ and $\mathbf{y}$. The index ranges from zero (completely different diets) to $\mathbf{1 0 0}$ (identical diets). The $\mathrm{P}_{\mathrm{xi}}$ and $\mathrm{P}_{\mathrm{yi}}$ values used to estimate the PS were the recalculated IRI (\%), in which unidentified crustaceans, decapods, crabs and shrimps were not considered, since these groups included Brachyura, Anomura, Caridea, Penaeidea, Peracarida and others. PS values over $60 \%$ were considered as high diet overlaps. In order to compare multiple samples, cluster analysis (Q-mode) was performed using the Percentage of Similarity Index and the UPGMA (unweighted pair-group arithmetic average clustering) method of hierarchical agglomeration (Sneath \& Sokal, 1973). Interspecific comparisons were made considering the diet of juveniles and adults on a seasonal basis.

\section{RESULTS}

Distribution of the species over the sampled area Neither species occurred in the shallowest area (site 6) near São Sebastião Island (Figs. 1 and 2). The skate $R$. agassizii showed broad distribution and was present at almost all locations (from $17 \mathrm{~m}$ to $50 \mathrm{~m}$ depth. A more restricted distribution was observed for $P$. extenta which was invariably sampled at site 7 and frequently caught around the $50 \mathrm{~m}$ isobath. High spatial overlaping $(67 \%)$ of both species occurred in summer 1986 and both winters. No overlap was observed during summer 1987 (Fig. 2).

\section{Length Distribution}

A total of 429 specimens of $R$. agassizii and 334 of $P$. extenta were captured in the area. The total length of $R$. agassizii collected over the period ranged from 80 to $580 \mathrm{~mm}$, though $69 \%$ of the individuals measured between $280-479 \mathrm{~mm}$ in length. The lengths of $P$. extenta ranged from 81 to $286 \mathrm{~mm}$, most of them (82\%) distributed in the 220-239 and 240-259 mm length classes (Table 1, Fig. 3).

\section{Overall diet}

The diet of Rioraja agassizii was composed of crustaceans (mainly caridean), fish and polychaetes (Table 2). Caridean shrimps occurred in $70 \%$ of the total stomachs and constituted $49 \%$ of the total prey number.

Fish were the most important item in terms of mass, despite their low numerical frequency. Other food categories presented low IRI values $(<$ $5.5 \%$ ). Psammobatis extenta is a crustacean feeder, preying mainly on amphipods, caridean shrimps and brachyurans, which occurred in at least $60 \%$ of the stomachs (Table 3). Amphipods accounted for $43 \%$ of the total number of prey items, and carideans for $48 \%$ of the total mass. Other items contributed less than $8 \%$ to the IRI (Tables 2 and 3 ).

\section{Seasonal comparisons}

Rioraja agassizii - A few empty stomachs of $R$. agassizii were collected $(0.9 \%)$ and the proportion of stomachs with at least half their volume of food was $52 \%$ (Fig. 4).

During both winters full and almost full stomachs predominated in the samples. Seasonal differences in prey ingested as well as in prey importance were evident throughout the year (Fig. 5A). From the classification analysis two major groups may be observed, one composed of both summers and the other of both springs and winters (Fig. 5B). In autumn 1986 the diet was similar to that of the summers and that of autumn 1987 to those of the springs and winters.

Seasonal changes in the diet followed the same pattern during both years. Caridean shrimps, fish (mainly teleostean) and amphipods were the most important prey groups in both springs, in addition to brachyuran crabs in spring 1986 (Fig. 5A, Table 4). 


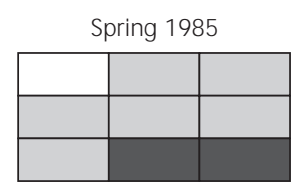

Summer 1986

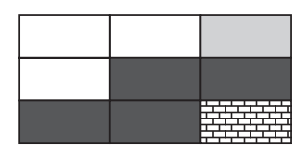

Autumn 1986
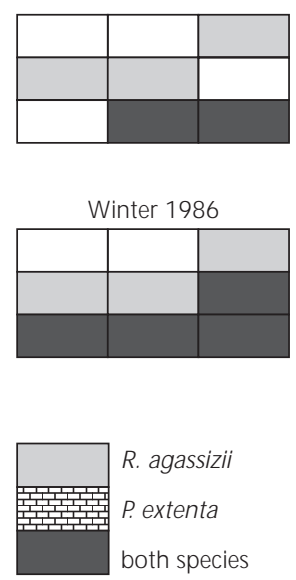

Fig. 2 - Spatial distribution of $R$. agassizii and P. extenta in the sampled area.
Fish and brachyuran crabs (portunids, leucosiids, majids and cancrids) were the major prey items during both summers, but amphipods (mainly the gammarids Ampelisca) were also important in summer 1986 and penaeidean shrimps (Trachypenaeus constrictus and Sicyonia sp.) in summer 1987. During autumn 1986, demersal fish were the main prey, while in autumn 1987 caridean shrimps (mainly Leptochela serratorbita) and brachyurans (portunids, leucosiids and cancrids) were the most important food. Shrimps made a major contribution to the diet during winter, especially the caridean L. serratorbita. Penaeidean shrimps were also important during winter 1987, mostly T. constrictus (Table 4, Figs. 4, 5A and 5B).

Psammobatis extenta - This species did not present any empty stomachs (Fig. 6). In summer 1986, spring 1986 and both winters, full stomachs were the most frequent in the sample. Almost empty and half full stomachs predominated in autumn 1986. Although prey composition had been similar over the year, the relative importance of the prey items changed (Fig. 7A). The dendogram illustrates two major groups, showing that the winter diets differed from those of other seasons (Fig. 7B). Amphipods and brachyurans were the major food during the springs, summers and autumns of the two years (Fig. 7A).

TABLE 1

Sampling periods, water temperature (T) and salinity $(\mathbf{S})$, number $(\mathrm{N})$ of specimens and size range (TL $=$ total length) of $R$. agassizii and $P$. extenta collected on Ubatuba shelf.

\begin{tabular}{|l|c|c|c|c|c|c|}
\hline \multirow{2}{*}{ Sampling } & \multicolumn{2}{|c|}{ Mean } & \multicolumn{2}{c|}{ R. agassizii } & \multicolumn{2}{c|}{ P. extenta } \\
\cline { 2 - 7 } & $\mathbf{T}^{\mathbf{0}} \mathbf{C}$ & $\mathbf{S}$ & $\mathbf{N}$ & $\mathbf{T L}(\mathbf{m m})$ & $\mathbf{N}$ & TL $(\mathbf{m m})$ \\
\hline Spring 1985 & 16.60 & 35.563 & 33 & $277-535$ & 50 & $81-262$ \\
\hline Summer 1986 & 16.94 & 35.505 & 27 & $192-504$ & 64 & $129-271$ \\
\hline Autumn 1986 & 22.41 & 35.669 & 93 & $96-538$ & 5 & $243-263$ \\
\hline Winter 1986 & 21.21 & 35.807 & 51 & $174-550$ & 48 & $130-286$ \\
\hline Subtotal & & 204 & $96-550$ & 167 & $81-286$ \\
\hline Spring 1986 & 18.70 & 35.606 & 79 & $89-580$ & 43 & $221-260$ \\
\hline Summer 1987 & 16.77 & 34.438 & 35 & $110-533$ & 36 & $133-265$ \\
\hline Autumn 1987 & 21.13 & 35.402 & 66 & $133-545$ & 44 & $206-276$ \\
\hline Winter 1987 & 20.85 & 34.738 & 45 & $184-532$ & 44 & $223-278$ \\
\hline Subtotal & & 225 & $89-580$ & 167 & $133-278$ \\
\hline TOTAL & & 429 & $89-580$ & 334 & $81-286$ \\
\hline
\end{tabular}


TABLE 2

Prey items of $R$. agassizii stomach contents for the total sample $(O=$ occurrence, $N=$ number, $M=$ mass (g) and IRI = Index of Relative Importance).

\begin{tabular}{|c|c|c|c|c|}
\hline \multirow{2}{*}{ Prey items } & \multicolumn{4}{|c|}{ Total } \\
\hline & $\% \mathrm{O}$ & $\% \mathbf{N}$ & $\% \mathbf{M}$ & $\%$ IRI \\
\hline POLYCHAETA & 21.88 & 2.14 & 0.26 & 0.51 \\
\hline CRUSTACEA (TOTAL) & 98.12 & 95.03 & $\mathbf{5 2 . 7 0}$ & 81.26 \\
\hline unidentified crustaceans & 20.71 & 2.81 & 0.02 & 0.57 \\
\hline crustaceans larvae & 0.24 & 0.04 & $<0.01$ & $<0.01$ \\
\hline unidentified decapods & 20.00 & 2.57 & 0.03 & 0.50 \\
\hline unidentified shrimps & 73.41 & 24.13 & 3.08 & 19.34 \\
\hline post larvae & 1.41 & 0.12 & $<0.01$ & $<0.01$ \\
\hline Caridea & 70.12 & 48.96 & 21.77 & 48.01 \\
\hline Penaeidea & 24.94 & 3.55 & 16.31 & 4.79 \\
\hline unidentified crabs & 15.76 & 1.27 & 1.78 & 0.46 \\
\hline megalopa & 0.24 & 0.01 & $<0.01$ & $<0.01$ \\
\hline Brachyura & 41.88 & 4.47 & 8.95 & 5.44 \\
\hline Anomura & 2.82 & 0.22 & 0.05 & 0.01 \\
\hline Amphipoda & 33.18 & 6.08 & 0.48 & 2.10 \\
\hline Cumacea & 2.12 & 0.13 & $<0.01$ & $<0.01$ \\
\hline Isopoda & 0.47 & 0.03 & $<0.01$ & $<0.01$ \\
\hline Mysidacea & 0.47 & 0.04 & $<0.01$ & $<0.01$ \\
\hline Stomatopoda & 5.41 & 0.36 & 0.21 & 0.03 \\
\hline Tanaidacea & 1.41 & 0.09 & 0.01 & $<0.01$ \\
\hline FISH & 37.65 & 2.98 & 47.04 & 18.23 \\
\hline TOTAL & & 7,583 & $291.54 \mathrm{~g}$ & 10,331 \\
\hline Stomachs analyzed & 425 & & & \\
\hline
\end{tabular}

Ampelisca brevisimulata and Portunus spinicarpus, were, respectively the most frequent amphipod and brachyuran species in the stomach contents (Table 5).

In autumn 1987, caridean shrimps were also important, Leptochela serratorbita being of particular note. During the winters, caridean shrimps (mainly L. serratorbita) predominated in the diet, contributing $82 \%$ and $78 \%$ to the IRI in 1986 and 1987, respectively. Despite the low IRI values of polychaetes, this item was consumed mainly during autumn, occurring in 50\% (1986) and 68\% (1987) of the stomachs analyzed (Table 5). During spring 1986 it occurred in $51 \%$ of the stomachs, rarely being ingested during both winters (Table 5, Figs. 6, 7A and $7 \mathrm{~B})$.

\section{Changes with fish length}

Preliminary examination showed that the diets of males and females of both skates species were very similar, thus data on stomach contents was pooled and comparisons were made between juveniles and adults.

Rioraja agassizii - Diet comparison within $50 \mathrm{~mm}$ length classes showed dietary changes with fish length (Fig. 8A, B). The diet of the specimens smaller than $180 \mathrm{~mm}$ differed from that of the larger ones due to the consumption of amphipods.

For larger skates, caridean shrimps predominated in the diet. Fish was important only for specimens over $480 \mathrm{~mm}$, which were all females. (Figs. 8A, B). 
Seasonal comparison between juvenile and adult diets showed that PS was higher during both winters, spring 1986 and autumn 1987. Shrimps (mostly caridean) were the main food items consumed by these groups in these periods (Fig. 9).
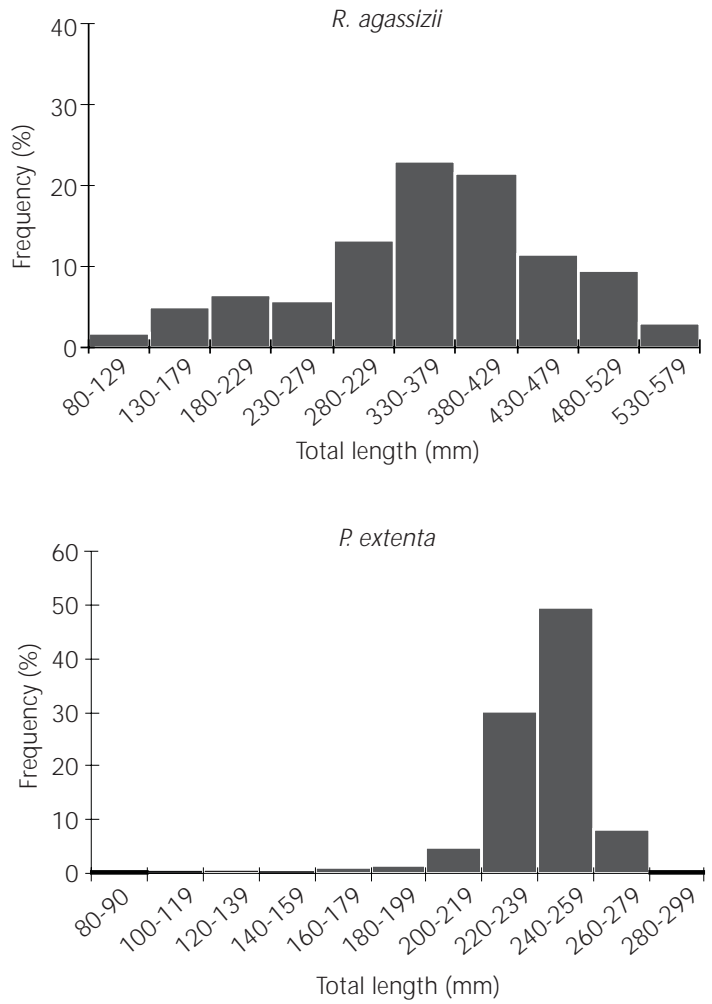

Fig. 3 - Length frequency distribution of $R$. agassizii and $P$. extenta from the overall sampling period.

Brachyurans were also important for adult diets in spring 1986 and autumn 1987.

In the other seasons juveniles and adults preyed on caridean and penaeidean shrimps, brachyuran crabs, amphipods and fish at different levels. Some differences were observed during spring, summer and autumn of the first year when amphipods were very important for juveniles but not for adults, while the inverse occurred for the item fish. During spring 1985, brachyurans were also important for juveniles and caridean shrimps for adults. In summer 1986, juveniles fed mainly on amphipods, brachyurans and fish, while adults consumed brachyurans and fish. In autumn 1986, amphipods and shrimps predominated in the juvenile diets, fish and shrimps being the most important food for adults. In summer 1987, juveniles fed mainly on brachyurans, followed by shrimps and amphipods. The major food items for adults were fish, penaeidean shrimps and brachyurans (Fig. 9). Psammobatis extenta - Specimens of 180 to $259 \mathrm{~mm}$ presented very similar diets, though differing from that of the larger skates (Figs. 10A, B).

Amphipods were the most important prey for smaller skates, decreasing in importance for the larger ones. As the skates grew the consumption of caridean shrimps increased (Figs. 10A, B).

The diets of juveniles and adults were very similar in spring 1985 and both summers, in which the amphipods were the main prey, followed by brachyurans (Fig. 11). Juveniles were not captured in the area during autumn and winter (Fig. 11).

\section{Interspecific comparisons}

Classification analysis showed that in the first year (1985/86), high interspecific feeding overlap occurred between juveniles of $R$. agassizii and juveniles/adults of $P$. extenta during summer, due to the consumption of amphipods (Figs. 9, 11 and 12A). The same was observed during autumn between juveniles of $R$. agassizzi and adults of $P$. extenta (Figs. 7A and 9).

Juveniles and adults of both species displayed a very similar diet during winter as well, feeding mainly on the caridean shrimp L. serratorbita.

Results of the classification were a little different in the second year (1996/97), showing two major groups (Fig. 12B). High feeding overlap occurred between the two species only during winter, when juveniles/adults of $R$. agassizii and adults of $P$. extenta consumed a large quantity of the caridean shrimp L. serratorbita (Figs. 7A and 9). The diet of $R$. agassizii during summer differed from that of the other groups, but juveniles of this species presented more feeding similarity with $P$. extenta (Figs. 12A, B).

\section{DISCUSSION}

The nature of the ingested food depends, first, on the morphology and feeding behavior of the fish, and secondly, on the composition and amount of food available (Pillay, 1952). The flat body and ventral mouth of the skates suggest a benthic feeding habit. Furthermore, rajids skates display mechanisms of oral suction which enables them to feed on benthic invertebrates (Moyle \& Cech-Jr., 1988). 
TABLE 3

Prey items of $P$. extenta stomach contents for the total sample $(O=$ occurrence, $N=$ number, $M=$ mass (g) and IRI = Index of Relative Importance).

\begin{tabular}{|c|c|c|c|c|}
\hline \multirow{2}{*}{ Prey items } & \multicolumn{4}{|c|}{ Total } \\
\hline & $\% \mathbf{O}$ & $\% \mathbf{N}$ & $\% \mathbf{M}$ & $\%$ IRI \\
\hline POLYCHAETA & 33.63 & 2.77 & 3.09 & 1.57 \\
\hline ECHINODERMATA & 0.30 & 0.01 & $<0.01$ & $<0.01$ \\
\hline MOLLUSCA & 0.30 & 0.01 & $<0.01$ & $<0.01$ \\
\hline CRUSTACEA (TOTAL) & 100.00 & 96.89 & 95.16 & 98.31 \\
\hline unidentified crustaceans & 17.72 & 1.95 & 0.87 & 0.40 \\
\hline unidentified decapods & 27.03 & 4.04 & 0.20 & 0.91 \\
\hline unidentified shrimps & 65.17 & 9.34 & 4.20 & 7.02 \\
\hline post larvae & 0.30 & 0.02 & $<0.01$ & $<0.01$ \\
\hline Caridea & 60.66 & 19.71 & 48.37 & 32.86 \\
\hline Penaeidea & 25.83 & 1.68 & 7.77 & 1.94 \\
\hline unidentified crabs & 14.11 & 1.15 & 0.50 & 0.19 \\
\hline megalopa & 11.11 & 1.46 & 0.40 & 0.16 \\
\hline Brachyura & 63.66 & 12.95 & 12.72 & 13.00 \\
\hline Anomura & 1.20 & 0.04 & 0.02 & $<0.01$ \\
\hline Palinura & 0.60 & 0.02 & 0.17 & $<0.01$ \\
\hline Amphipoda & 84.38 & 42.75 & 19.21 & 41.60 \\
\hline Cumacea & 15.32 & 1.06 & 0.21 & 0.16 \\
\hline Isopoda & 2.70 & 0.11 & 0.01 & $<0.01$ \\
\hline Mysidacea & 4.50 & 0.25 & 0.07 & 0.01 \\
\hline Stomatopoda & 8.11 & 0.35 & 0.44 & 0.05 \\
\hline SIPUNCULA & 0.30 & 0.01 & $<0.01$ & $<0.01$ \\
\hline FISH & 7.51 & 0.29 & 1.74 & 0.12 \\
\hline TOTAL & & 9,119 & $77.879 \mathrm{~g}$ & 12,567 \\
\hline Stomachs analyzed & 333 & & & \\
\hline
\end{tabular}

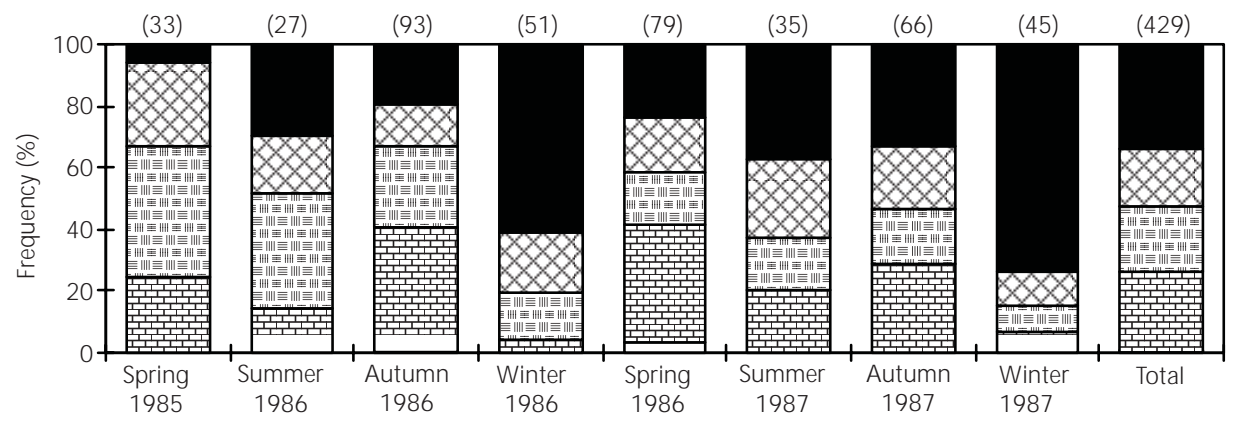

$$
\square \text { Empty } \square>0 \%-25 \% \text { 团> 25\%-50\% } \quad \square>50 \%-75 \% \quad \square>75 \%
$$

Fig. 4 - Seasonal variation of the degree of stomach fullness in R. agassizii. 

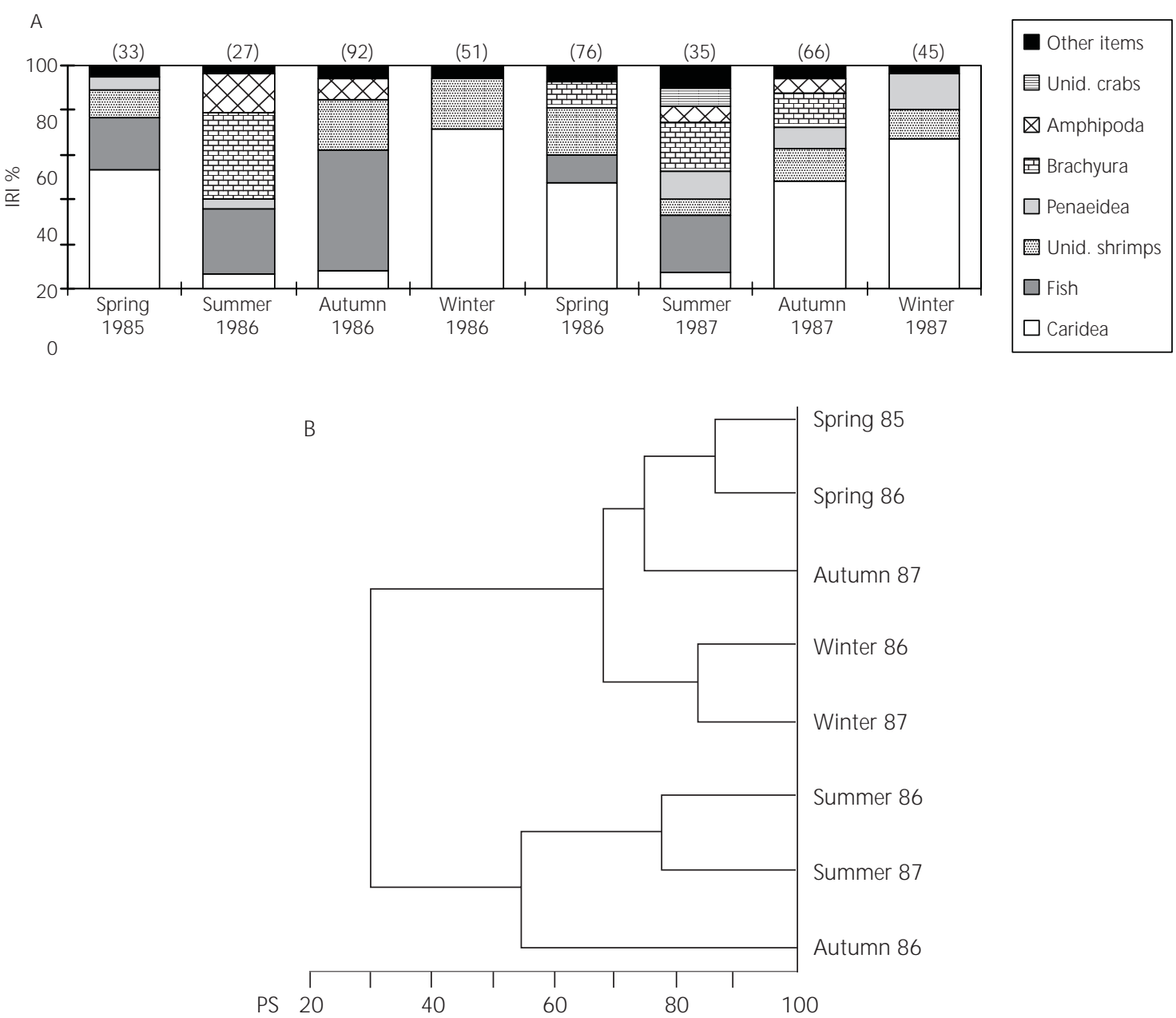

Fig. 5 - A) Seasonal variation of the stomach contents of $R$. agassizii (IRI = Index of Relative Importance; PS = Percentage of Similarity, number in brackets is of stomachs analyzed). B) Dendogram showing temporal feeding similarity.

The results demonstrated that Rioraja agassizii and Psammobatis extenta feed on benthic prey items, mainly crustaceans. The dominance of this group in the diet of many rajids has been observed by many authors (McEachran et al., 1976; Ajayi, 1982; Abd El-Aziz, 1986; Pedersen, 1995).

Other groups such as polychaetes, molluscs and fish also display important roles in the feeding of some skates.

Many studies on the natural feeding of fish draw attention to the large variety of prey in the stomach content and a generalist character has been attributed to the group (Tyler, 1972). However, studies concerning food resource partition in the demersal fish community reveal fish specialization when analysis of the main prey items is made. In spite of the broad food spectrum, a few prey categories predominated in the diet of both skates. The most important prey items for both species were amphipods, carideans and brachyurans, in addition to fish for R. agassizii. Polychaete and penaeidean shrimps were also important in some seasons.

Data on prey habitat is a helpful indicator of the predator's feeding habits. The most abundant amphipod consumed by the skates was A. brevisimulata, a tubicolous species of the infauna that feeds on organic detritus (Mills, 1967). Most of the shrimps, crabs and fish eaten by the skates are bottom dwellers as well. Despite the pelagic habit of the shrimp L. serratorbita, this species displays vertical migration (Jones, 1982) and could have been eaten by the skates near the bottom. 
TABLE 4

List of prey items consumed by $R$. agassizii. Frequency of occurrence $(\% \mathbf{O})$.

\begin{tabular}{|c|c|c|c|c|c|c|c|c|c|}
\hline Prey taxon & $\% 0$ & $\begin{array}{c}\text { Spring } \\
85\end{array}$ & $\begin{array}{c}\text { Summer } \\
86\end{array}$ & $\begin{array}{l}\text { Autumn } \\
86\end{array}$ & $\begin{array}{c}\text { Winter } \\
86\end{array}$ & $\begin{array}{c}\text { Spring } \\
86\end{array}$ & $\begin{array}{c}\text { Summer } \\
87\end{array}$ & $\begin{array}{c}\text { Autumn } \\
\quad 87\end{array}$ & $\begin{array}{c}\text { Winter } \\
87\end{array}$ \\
\hline \multirow{5}{*}{ POLYCHAETA } & Total & 3 & 4 & 37 & 10 & 20 & 23 & 36 & \\
\hline & Aphroditacea & & & & 2 & & & 9 & \\
\hline & Sigalionidae & & 4 & 9 & & 13 & 9 & 9 & \\
\hline & Polynoidae & & & & & 1 & & & \\
\hline & Onuphidae & 3 & & 10 & & & & & \\
\hline \multicolumn{10}{|l|}{ CRUSTACEA } \\
\hline \multirow{18}{*}{ Caridea } & Total & 70 & 41 & 50 & 100 & 75 & 37 & 79 & 100 \\
\hline & Pasiphaeidae & & & & & & & & \\
\hline & Leptochela sp. & 30 & 7 & 4 & 22 & 12 & & 42 & 84 \\
\hline & L. serratorbita & 58 & 19 & 4 & 98 & 62 & 23 & 73 & 98 \\
\hline & L. papulata & 3 & 11 & 1 & 20 & 1 & & 12 & 2 \\
\hline & Processidae & & & 4 & & 1 & & & \\
\hline & Processa sp. & 9 & 4 & 24 & 6 & 24 & 14 & 6 & \\
\hline & P. hemphilli & 9 & & 18 & 12 & 12 & & 2 & \\
\hline & P. profunda & & & 1 & 2 & & & & \\
\hline & Ogyrididae & & & & & & & & \\
\hline & Ogyrides sp. & 3 & & & & 7 & 6 & & \\
\hline & O. alphaerostris & 3 & 4 & & & 12 & 11 & 3 & 2 \\
\hline & Hipollytidae & & & & & & & & 2 \\
\hline & $\begin{array}{l}\text { Latreutes } \\
\text { parvulus }\end{array}$ & 3 & & & & & & & \\
\hline & Alpheidae & & 4 & & & & & & \\
\hline & Alpheus sp. & & & 4 & & & & & \\
\hline & Automate sp. & & & 1 & & & & & \\
\hline & Palaemonidae & & & & 2 & 1 & & & \\
\hline \multirow{12}{*}{ Penaeidea } & Total & 36 & 19 & 3 & 37 & 14 & 23 & 23 & 73 \\
\hline & Solenoceridae & 6 & & & & & 3 & 8 & 7 \\
\hline & Solenocera sp. & & & & & & & & 4 \\
\hline & Pleoticus sp. & 3 & & & & & & & \\
\hline & $\begin{array}{l}\text { Pleoticus } \\
\text { muelleri }\end{array}$ & 6 & & & & & & 2 & \\
\hline & Mesopenaeus sp. & 3 & & & & & & & \\
\hline & $\begin{array}{l}\text { Mesopenaeus } \\
\text { tropicalis }\end{array}$ & 3 & 4 & & & & 3 & & \\
\hline & Penaeidae & 3 & 4 & & 20 & 5 & & & 13 \\
\hline & Penaeus sp. & & & 1 & & & & & \\
\hline & $\begin{array}{l}\text { Parapenaeus } \\
\text { americanus }\end{array}$ & & & & 10 & & & & \\
\hline & $\begin{array}{l}\text { Trachypenaeus } \\
\text { constrictus }\end{array}$ & 9 & & 1 & 4 & 7 & 9 & 6 & 40 \\
\hline & Sicyoniidae & 3 & 4 & 1 & & & & 2 & \\
\hline
\end{tabular}


TABLE 4 (Continued)

\begin{tabular}{|c|c|c|c|c|c|c|c|c|c|}
\hline Prey taxon & $\% \mathbf{O}$ & $\begin{array}{c}\text { Spring } \\
85\end{array}$ & $\begin{array}{c}\text { Summer } \\
86\end{array}$ & $\begin{array}{c}\text { Autumn } \\
86\end{array}$ & $\begin{array}{c}\text { Winter } \\
86\end{array}$ & $\begin{array}{c}\text { Spring } \\
86\end{array}$ & $\begin{array}{c}\text { Summer } \\
87\end{array}$ & $\begin{array}{c}\text { Autumn } \\
87\end{array}$ & $\begin{array}{c}\text { Winter } \\
87\end{array}$ \\
\hline & Sicyonia sp. & & & & 8 & 4 & 11 & & 4 \\
\hline & Sergestidae & & & & & & & & \\
\hline & Acetes sp. & 3 & & & & & & & \\
\hline \multirow{17}{*}{ Brachyura } & Total & 48 & 63 & 35 & 22 & 47 & 63 & 52 & 22 \\
\hline & Portuninae & & & 4 & & & & & \\
\hline & Portunidae & 9 & 30 & 15 & 2 & 17 & 49 & 17 & 2 \\
\hline & Portunus sp. & 6 & & 2 & & 3 & 3 & 3 & \\
\hline & P. spinicarpus & & 4 & & 2 & 20 & & 11 & \\
\hline & Callinectes sp. & & & & & 1 & & & \\
\hline & Majidae & 12 & 11 & & & 7 & 11 & & \\
\hline & Libinia sp. & & & & & & 3 & & \\
\hline & Pisinae sp. & & & & & & 3 & & \\
\hline & Leucosiidae & 3 & 4 & 1 & 2 & 1 & & 5 & \\
\hline & Persephona sp. & & & & 1 & 5 & 3 & & 9 \\
\hline & P. mediterranea & & & & 4 & & & & \\
\hline & Cancridae & & & & & & & & \\
\hline & Cancer sp. & 3 & & 11 & & 7 & 6 & 3 & 11 \\
\hline & Iliinae & & & & & 3 & & & \\
\hline & Parthenopidae & & & & & & & & 2 \\
\hline & Cryptopodia sp. & & & & & 1 & & & 2 \\
\hline \multirow{3}{*}{ Anomura } & Total & & 4 & & & 1 & 29 & & \\
\hline & Porcellanidae & & & & & & 26 & & \\
\hline & Paguridae & & 4 & & & 1 & & & \\
\hline \multirow{7}{*}{ Amphipoda } & Total & 18 & 52 & 47 & 16 & 33 & 46 & 39 & 7 \\
\hline & Gammaridea & & 7 & 9 & 4 & 4 & 3 & 3 & \\
\hline & Ampelisca sp. & 9 & 33 & 21 & 8 & 11 & 26 & 27 & 7 \\
\hline & A. brevisimulata & 6 & 19 & 27 & 4 & 17 & 29 & 26 & \\
\hline & A. pugetica & & 7 & 2 & & 3 & 3 & 3 & \\
\hline & Hiperiidae & & & 2 & & & & & \\
\hline & Caprellidae & & & 1 & & & & & \\
\hline \multirow{2}{*}{ Cumacea } & Total & & & 3 & & & & & \\
\hline & Diastylidae & & & 1 & & & & & \\
\hline Mysidacea & Mysidae & & & & 2 & & & & \\
\hline \multirow{2}{*}{ Stomatopoda } & Total & & & & & & 29 & & \\
\hline & Squila sp. & & & & & & 3 & & \\
\hline \multirow{4}{*}{ FISH } & Total & 27 & 59 & 57 & 14 & 47 & 40 & 24 & \\
\hline & Bothidae & & & 1 & & 1 & & & \\
\hline & Symphurus sp. & 3 & & & & & & & \\
\hline & Ophidiidae & 3 & & & & & & & \\
\hline
\end{tabular}


TABLE 4 (Continued)

\begin{tabular}{|c|c|c|c|c|c|c|c|c|c|}
\hline Prey taxon & $\% 0$ & $\begin{array}{l}\text { Spring } \\
85\end{array}$ & $\begin{array}{c}\text { Summer } \\
86\end{array}$ & $\begin{array}{c}\text { Autumn } \\
86\end{array}$ & $\begin{array}{c}\text { Winter } \\
86\end{array}$ & $\begin{array}{c}\text { Spring } \\
86\end{array}$ & $\begin{array}{c}\text { Summer } \\
87\end{array}$ & $\begin{array}{c}\text { Autumn } \\
87\end{array}$ & $\begin{array}{c}\text { Winter } \\
87\end{array}$ \\
\hline \multirow{12}{*}{ FISH } & Scorpaenidae & & 4 & & & 1 & & & \\
\hline & Serranidae & & & 1 & & & & & \\
\hline & Bathrachoididae & & & & & & & & \\
\hline & $\begin{array}{l}\text { Porichthys } \\
\text { porosissimus }\end{array}$ & & & 1 & & & & & \\
\hline & Ophichthidae & & & & & & & & \\
\hline & Ophichthus sp. & & & & & 1 & & & \\
\hline & Ophidiidae & & & & & & 6 & & \\
\hline & Ophidion sp. & & & & & & 3 & & \\
\hline & Bregmacerotidae & & & & & & & & \\
\hline & Bregmacerus sp. & & & & & & & 2 & \\
\hline & $\begin{array}{l}\text { Bregmacerus } \\
\text { atlanticus }\end{array}$ & & & 1 & & & & & \\
\hline & Rajidae & 3 & & & & & & & \\
\hline $\begin{array}{l}\text { Total stomachs } \\
\text { analyzed }\end{array}$ & & 33 & 27 & 92 & 51 & 76 & 35 & 66 & 45 \\
\hline
\end{tabular}

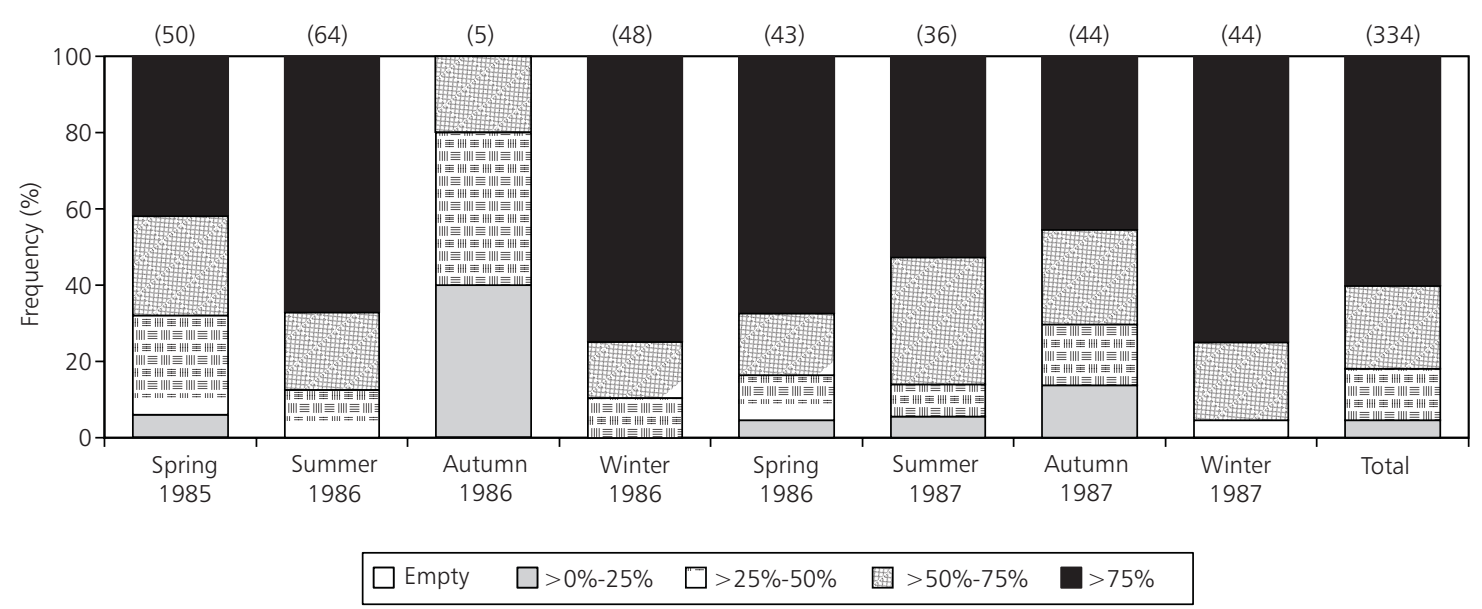

Fig. 6 - Seasonal variation of the degree of stomach fullness in P. extenta.

The degree of digestion of the polychaetes in the stomach contents made it difficult to identify this group to specific level, therefore data on this item has certainly been underestimated. Polychaetes are the most important group in the macrofauna on the Ubatuba shelf (Pires-Vanin, 1993) and represent an important resource in the area studied. This prey were more frequently eaten by $P$. extenta than by R. agassizii. According to the trophic guilds of polychaetes defined by Fauchald \& Jumars (1979), R. agassizii consumed mainly carnivore polychaetes (aphroditacea, sigalionids, onuphids and polynoids) whereas $P$. extenta consumed not only carnivores (aphroditacea, sigalionids and onuphids) but surface deposit feeders (terebellids) and subsurface deposit feeders as well (capitelids and maldanids), suggesting that this species digs into the sediment in search for food. 
TABLE 5

List of prey items consumed by $P$. extenta. Frequency of occurrence $(\% \mathrm{O})$.

\begin{tabular}{|c|c|c|c|c|c|c|c|c|c|}
\hline Prey taxon & $\% \mathrm{O}$ & Spring 85 & Summer 86 & Autumn 86 & Winter 86 & Spring 86 & Summer 87 & Autumn 87 & Winter 87 \\
\hline \multirow{7}{*}{ POLYCHAETA } & Total & 32 & 39 & 50 & 13 & 51 & 28 & 68 & \\
\hline & Aphroditacea & & 27 & 50 & 6 & 16 & 6 & 5 & \\
\hline & Capitelidae & & 2 & & & 7 & 3 & & \\
\hline & Maldanidae & 2 & 13 & & 2 & 7 & & 14 & \\
\hline & Sigalionidae & 4 & & & & 23 & & 7 & \\
\hline & Onuphidae & & & & & 2 & & & \\
\hline & Terebellidae & & & & & 2 & & & \\
\hline \multirow[b]{2}{*}{ ECHINODERMATA } & Total & 2 & & & & & & & \\
\hline & $\begin{array}{l}\text { Spantagoidea } \\
\text { (larvae) }\end{array}$ & 2 & & & & & & & \\
\hline \multirow{2}{*}{ MOLLUSCA } & Total & 2 & & & & & & & \\
\hline & Pelecypoda & 2 & & & & & & & \\
\hline CRUSTACEA & & & & & & & & & \\
\hline \multirow{18}{*}{ Caridea } & Total & 38 & 47 & & 98 & 70 & 11 & 66 & 98 \\
\hline & Pasiphaeidae & & & & & & & & \\
\hline & Leptochela sp. & 2 & & & 46 & 23 & & 36 & 91 \\
\hline & L. serratorbita & 26 & 2 & & 98 & 47 & 6 & 61 & 95 \\
\hline & L. papulata & & 41 & & 21 & 2 & & 2 & \\
\hline & Processidae & & & & & 2 & & & \\
\hline & Processa sp. & 2 & & & 8 & 9 & & 7 & 2 \\
\hline & P. hemphilli & 2 & & & 4 & 19 & & & \\
\hline & Ogyrididae & & & & & & & & \\
\hline & $\begin{array}{l}\text { Ogyrides } \\
\text { alphaerostris }\end{array}$ & & & & & & & & 2 \\
\hline & Hippolytidae & 2 & & & & & 3 & & \\
\hline & Latreutes sp. & 4 & & & & & & & \\
\hline & $\begin{array}{l}\text { Latreutes } \\
\text { parvulus }\end{array}$ & 10 & & & & & 3 & & 2 \\
\hline & Alpheidae & & 5 & & & 5 & & & 2 \\
\hline & $\begin{array}{l}\text { Alpheus } \\
\text { amblyonyx }\end{array}$ & 2 & & & & & & & \\
\hline & Hipolitidae & & & & & & & & \\
\hline & $\begin{array}{l}\text { Latreutes } \\
\text { parvulus }\end{array}$ & & & & & & & & \\
\hline & Cangronidae & & 2 & & & & & & \\
\hline \multirow{11}{*}{ Penaeidea } & Total & 32 & 25 & & 29 & 16 & 14 & 9 & 55 \\
\hline & Solenoceridae & 2 & 3 & & & & & & 2 \\
\hline & Pleoticus sp. & 4 & & & & & & & \\
\hline & $\begin{array}{l}\text { Pleoticus } \\
\text { muelleri }\end{array}$ & 16 & 13 & & & 2 & 11 & 7 & 7 \\
\hline & Mesopenaeus sp. & & & & & & & & \\
\hline & $\begin{array}{l}\text { Mesopenaeus } \\
\text { tropicalis }\end{array}$ & & & & & & & & \\
\hline & Penaeidae & & 2 & & 15 & & & & 7 \\
\hline & $\begin{array}{l}\text { Trachypenaeus } \\
\text { constrictus }\end{array}$ & & & & & 2 & & & 2 \\
\hline & Sicyoniidae & & & & & & & & 9 \\
\hline & Sicyonia sp. & & & & 2 & 5 & & & 2 \\
\hline & Sicyonia typica & & & & 2 & & & & \\
\hline \multirow{15}{*}{ Brachyura } & Total & 92 & 83 & 100 & 4 & 91 & 89 & 77 & 5 \\
\hline & Portunidae & 80 & 41 & 25 & & 58 & 81 & 64 & \\
\hline & Portunus sp. & & 3 & & & 12 & 3 & 2 & \\
\hline & P. spinicarpus & 18 & 42 & 50 & & 40 & 61 & 36 & \\
\hline & Callinectes sp. & 2 & & & & 2 & & & \\
\hline & Majidae & 8 & 13 & & & 28 & 6 & & \\
\hline & Leucosiidae & & 2 & & & 2 & & & \\
\hline & Persephona sp. & 2 & & & & 5 & & & \\
\hline & P. mediterranea & 4 & & & & 7 & 3 & & 2 \\
\hline & Micropsis sp. & & & & & 2 & & & \\
\hline & Cancridae & & & & & & 3 & & \\
\hline & Cancer sp. & 2 & 2 & & & 2 & & & \\
\hline & Parthenopidae & & 2 & & & & & & \\
\hline & Pinotheridae & & & & & & & & \\
\hline & Parapinnixa sp. & & & & & 2 & & & \\
\hline
\end{tabular}


TABLE 5 (Continued)

\begin{tabular}{|c|c|c|c|c|c|c|c|c|c|}
\hline Prey taxon & O\% & \begin{tabular}{|l|} 
Spring 85 \\
\end{tabular} & Summer 86 & Autumn 86 & Winter 86 & \begin{tabular}{|l|} 
Spring 86 \\
\end{tabular} & Summer 87 & Autumn 87 & Winter 87 \\
\hline \multirow{4}{*}{ Anomura } & Total & 4 & 2 & & & & & & \\
\hline & Galatheidae & 2 & & & & & & & \\
\hline & Hippidae & & & & & & & & \\
\hline & Emerita sp. & & 2 & & & & & & \\
\hline \multirow{3}{*}{ Palinura } & Total & & & & & 2 & & & \\
\hline & Scylaridae & & & & & & & & \\
\hline & Scylarus sp. & & & & & 2 & & & \\
\hline \multirow{19}{*}{ Amphipoda } & Total & 100 & 100 & 100 & 48 & 100 & 94 & 82 & 61 \\
\hline & Gammaridea & 44 & 20 & & 4 & 21 & 6 & 5 & \\
\hline & Ampeliscidae & & & & & & & & \\
\hline & Ampelisca sp. & 80 & 75 & 50 & 33 & 84 & 67 & 70 & 32 \\
\hline & A. brevisimulata & 82 & 98 & 50 & 31 & 95 & 92 & 68 & 43 \\
\hline & A. pugetica & 30 & 45 & & 2 & 40 & 11 & 20 & \\
\hline & Hiperiidae & 2 & & & & 2 & & & \\
\hline & Liljeborgiidae & & & & & & 3 & & \\
\hline & $\begin{array}{l}\text { Liljeborgia } \\
\text { quinquidentata }\end{array}$ & & & & & 2 & 3 & & \\
\hline & Phoxocephalidae & & & & & & & & \\
\hline & $\begin{array}{l}\text { Heterophoxus } \\
\text { videns }\end{array}$ & & & & & 2 & 6 & & \\
\hline & Dulichiidae & & & & & & & & \\
\hline & Podocerus sp. & 4 & & & & & & & \\
\hline & P. brasiliensis & 12 & & & & & & & \\
\hline & Stenothoidae & & & & & & & & \\
\hline & Stenothoe valida & 2 & & & & & & & \\
\hline & Hyale media & 2 & & & & & & & \\
\hline & Amphilocus sp. & 2 & & & & & & & \\
\hline & Caprellidae & & 2 & & & & & & \\
\hline Cumacea & Total & & & 25 & & & & & \\
\hline Isopoda & Asellota sp. & & 2 & & & & & & \\
\hline Mysidacea & Total & & & & 17 & & & & \\
\hline \multirow{2}{*}{ Stomatopoda } & Total & 8 & 27 & & & & 8 & & \\
\hline & Squila sp. & 2 & 2 & & & & & & \\
\hline \multirow{2}{*}{ FISH } & Total & 6 & 5 & & 4 & 23 & 8 & 9 & \\
\hline & Bregmacerotidae & & & & & 5 & & & \\
\hline $\begin{array}{c}\text { Total Stomachs } \\
\text { Analyzed }\end{array}$ & & 50 & 64 & 4 & 48 & 43 & 36 & 44 & 44 \\
\hline
\end{tabular}

The amount and quality of the food ingested by fish are associated with the diel cycle, seasonal variations of the food, fish size, territorial behavior and differential digestion rate (Bowen, 1983).

In relation to feeding activity, $R$. agassizii (Soares et al., 1999) and $R$. erinacea (McEachran et al., 1976) feed continuously during a 24-hour cycle. In skates, the detection and capture of a prey involve mainly smell, touch and electroreception associated with feeding behavior (Raschi \& Adams, 1988; Berestovskiy, 1989).

As sight seems to be less important for prey detection, the food intake by skates is less dependent on the light/dark cycle. The low frequency of empty stomachs verified in $R$. agassizii and $P$. extenta, as well as in some rajids (Ezzat et al., 1987; Abd El-Aziz, 1986), may be the result of continuous feeding activity.
This behavior may be associated with the high abundance and low energetic value of their main prey items (amphipods, carideans and crabs) which would impel this species to a continuous feeding intake in order to meet their energetic requirements.

The seasonal shift in the diet of teleosts (Blaber $\&$ Bulman, 1987) and some rajids (Ajayi, 1982; Abd El-Aziz, 1986) has been attributed to the fluctuation in the abundance of prey items. The structure and dynamics of the benthic macrofauna (Pires-Vanin, 1993) and megafauna (Pires, 1992) on the Ubatuba shelf are associated with the seasonal dynamics of the water masses. Seasonality in the R. agassizii and $P$. extenta diets seems to be related to food availability since the distribution of their major prey items is related to seasonal environmental changes. The main brachyurans eaten by the skates were portunids, majids, callapids and leucosiids. The most 
abundant of them, Portunus spinicarpus, occurs on the frontal edge of the cold South Atlantic Coastal Water (SACW), and its distribution is associated with the dynamics of this water mass (Sartor, 1989). According to Matsuura (1986), the intrusion of SACW onto the inner shelf occurs through the bottom layer during late spring and early summer, when a thermocline can be observed. During autumn and winter, this water mass moves back to the edge of the continental shelf and the water column temperature becomes homogeneous. Therefore, $P$. spinicarpus is more abundant on the inner shelf during spring and summer, although juveniles can occur throughout the year.

This would explain the high frequency of portunids in the stomach contents of $R$. agassizii during summer, since this species is distributed throughout the area, occurring both in the shallow and deep parts of the inner shelf. The consumption of brachyuran crabs (mainly portunids) by $P$. extenta over the year, except during winter, may be related to the differential occurrence of this species around the $50 \mathrm{~m}$ isobath, where portunid crabs are available throughout the year.
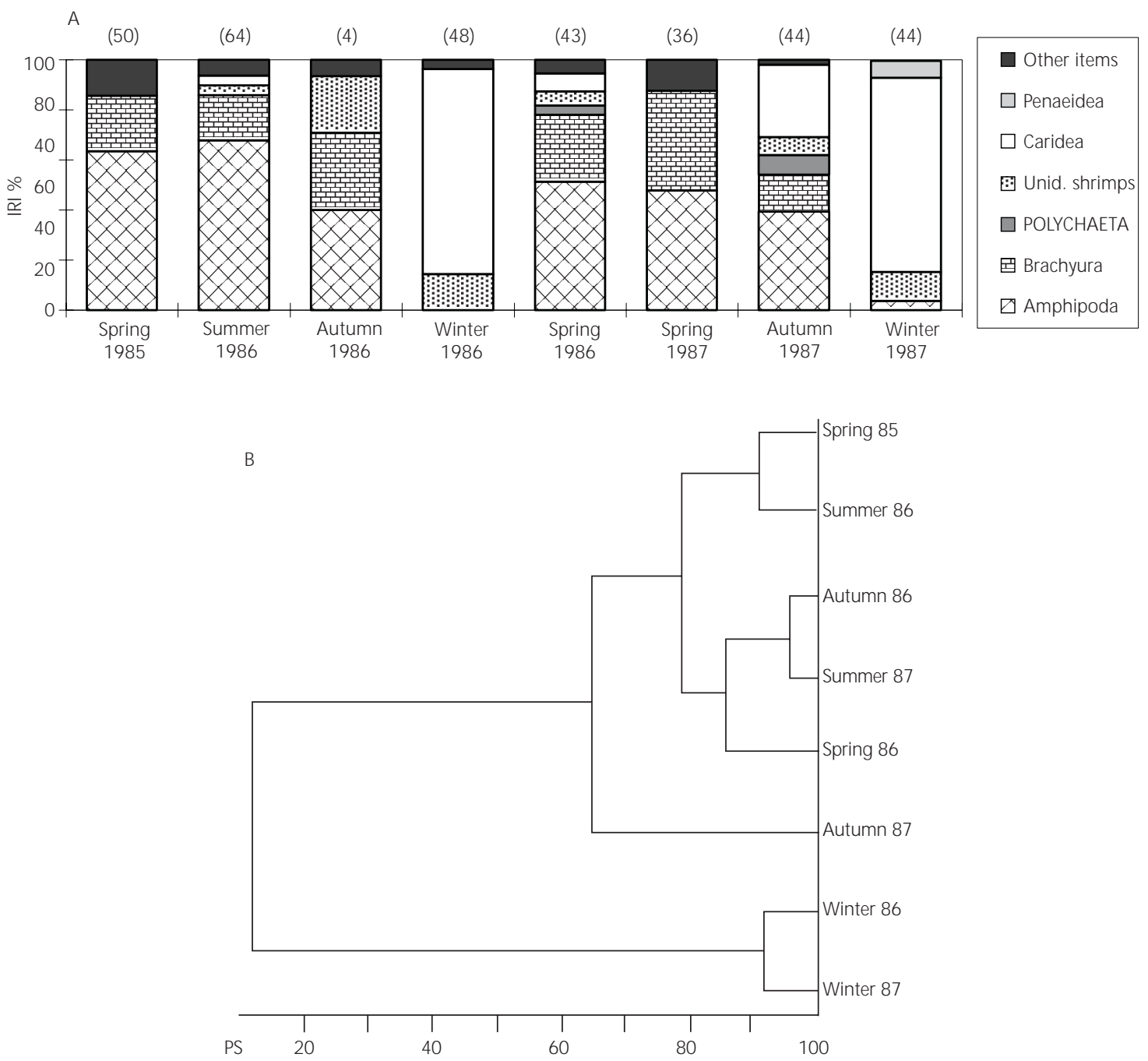

Fig. 7 - A) Seasonal variation of the stomach contents of $P$. extenta $($ IRI $=$ Index of Relative Importance; PS = Percentage of Similarity, number in brackets is of stomachs analyzed. B) Dendogram showing temporal feeding similarity. 
The shrimp L. serratorbita was the main food for both skates during winter, when the cold South Atlantic Coastal Water (SACW) was further offshore and the inner shelf was occupied by the warm Coastal Water (CW) (Castro Filho et al., 1987). Rios (1994) verified that this shrimp was the major prey for the croaker Ctenosciaena gracilicirrhus during winter time, in the same region. The greater abundance of L. serratorbita seems to be associated with high water temperatures.

This shrimp was also an important food for R. agassizii in both the springs and in autumn 1987, whereas $P$. extenta was feeding on amphipods during these periods.
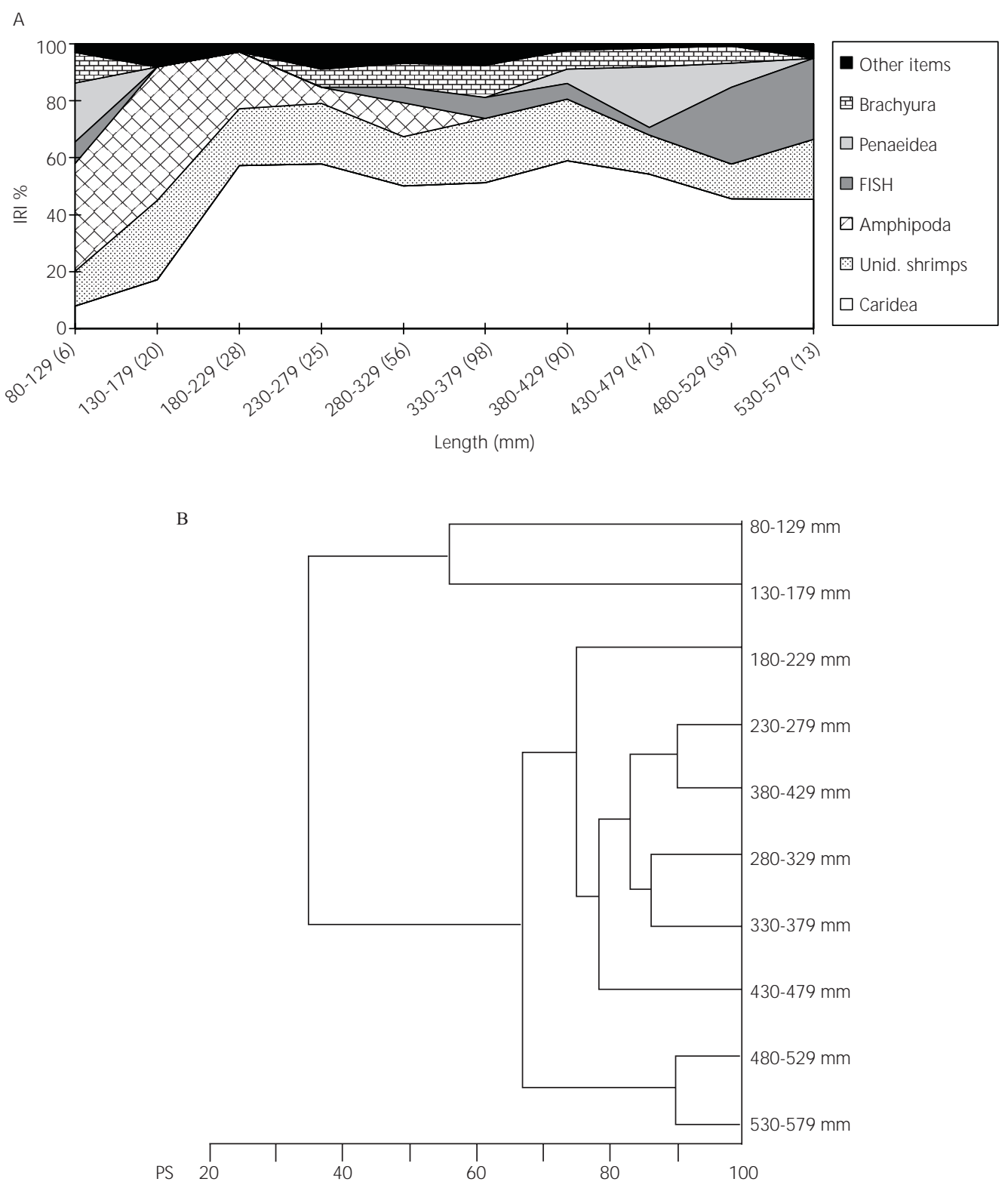

Fig. 8 - A) Ontogenetic variation of the Index of Relative Importance (IRI\%) of prey items consumed by R. agassizii (PS = Percentage of Similarity, number in brackets is of stomachs analyzed). B) Dendogram showing feeding similarity among length classes. 
The most representative family of amphipods in the Ubatuba region (Valério-Berardo, 1992) was the ampeliscid, which was the most important prey for $P$. extenta during spring, summer and autumn. During winter, it fed on caridean shrimps and the diet shift must be associated with the decrease of the Ampelisca brevisimulata population, which did not occur on the inner shelf during winter due to bottom turbulence caused by winds (Valério-Berardo, 1992), associated with the availability of $L$. serratorbita.

Juveniles

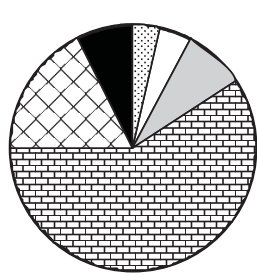

$3=N=30$

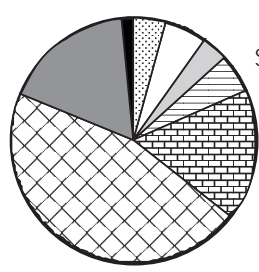

Summer 1986 $\mathrm{PS}=53$

$10=\mathrm{N}=17$
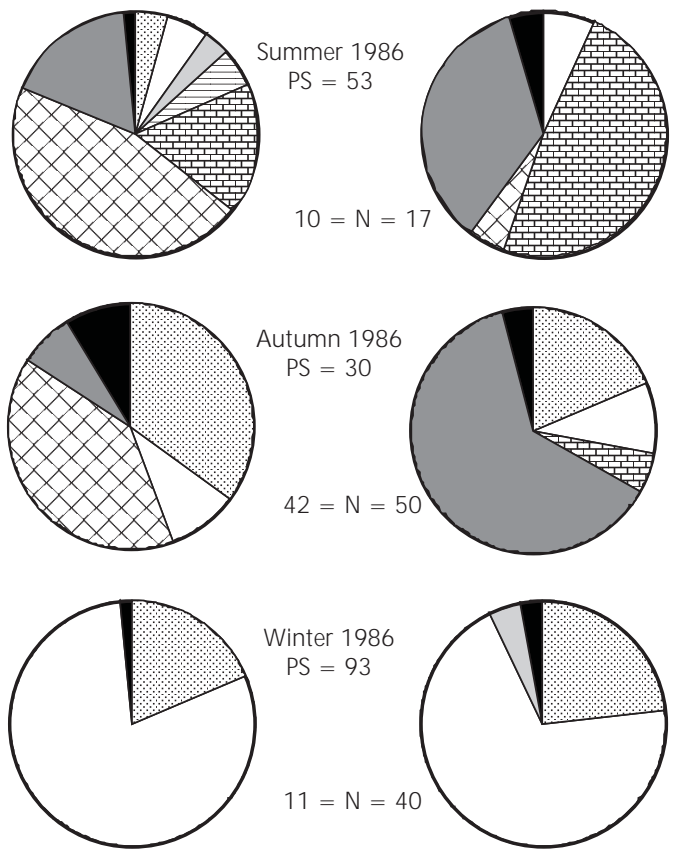

The structure and dynamics of the benthic macrofauna (Pires-Vanin, 1993) and megafauna (Pires, 1992) of the Ubatuba shelf are greatly influenced by the dynamics of the water masses and the seasonal diet shift presented by some brachyuran crabs in the region is related to prey availability (Petti, 1990).

Selectivity in prey size (Werner \& Hall, 1974), prey abundance (Griffiths, 1975), availability and mobility (Moyle \& Cech-Jr., 1988) are important features for prey selection by predators.

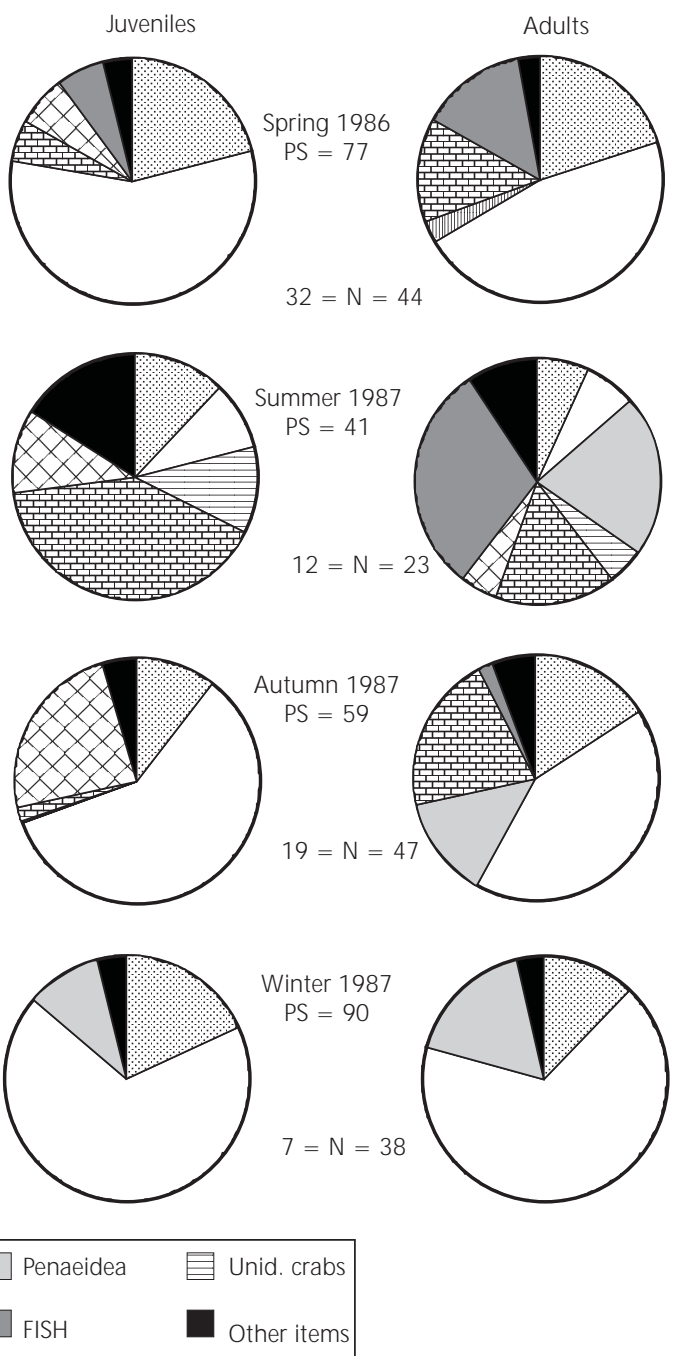

Fig. 9 - Index of Relative Importance (IRI\%) of prey items consumed by juveniles and adults of R. agassizii, by season (PS $=$ Percentage of Similarity, $\mathrm{N}=$ number of stomachs analyzed). 
A
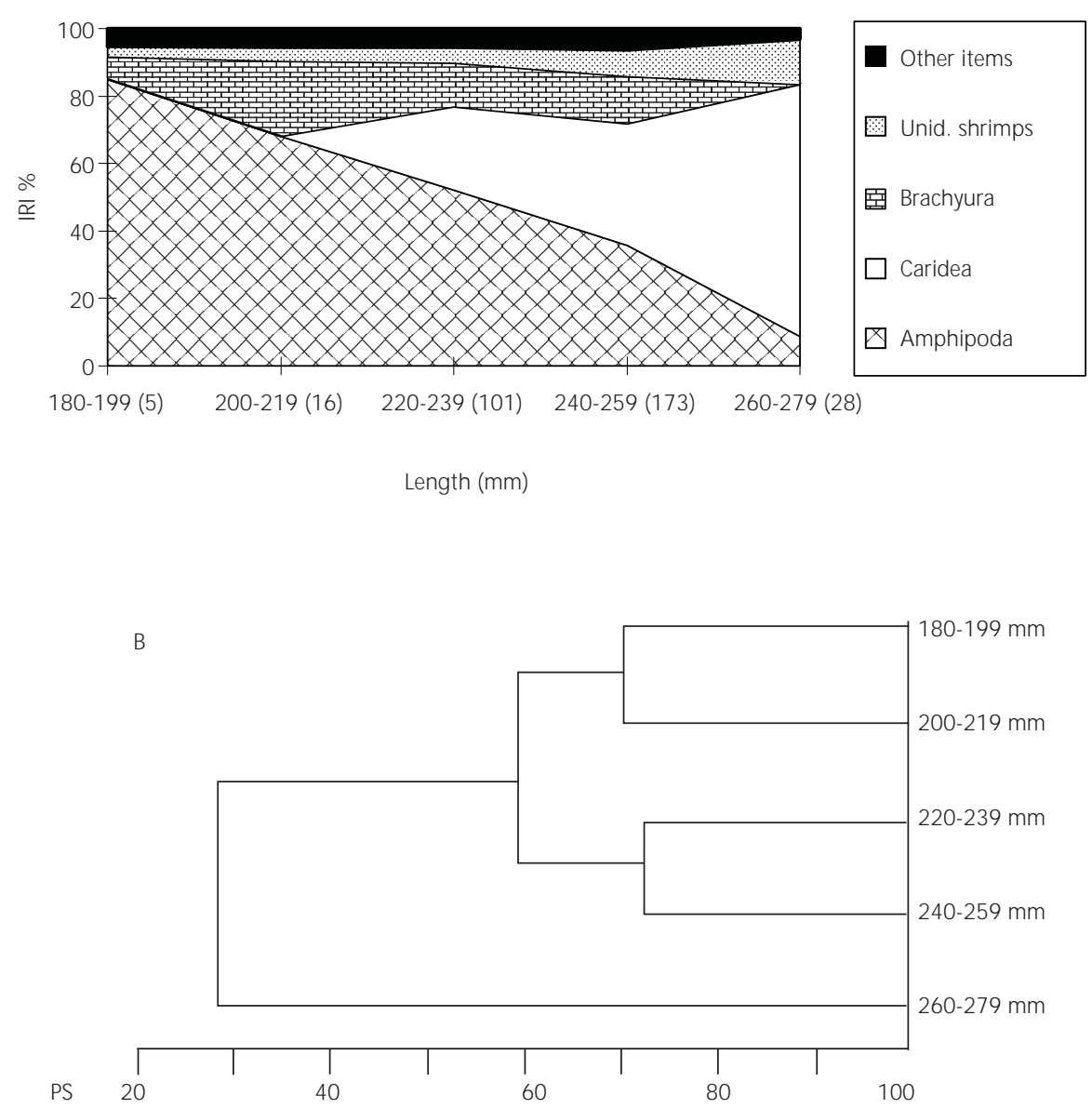

Fig. 10 - A) Ontogenetic variation in the Index of Relative Importance (IRI\%) of prey items consumed by $P$. extenta $($ PS $=$ Percentage of Similarity, number in brackets is of stomachs analyzed). B) Dendogram showing feeding similarity among length classes.

Usually, larger fish show greater ability in capturing larger prey items, in order to be able to meet their energetic requirements, feeding on small amounts of larger prey (Keast, 1977).

This strategy provides a better energy budget than does feeding on smaller and more abundant prey (Kerr, 1971).

Smaller specimens of both skates fed mainly on a large quantity of $A$. brevisimulata and $L$. serratorbita, small organisms that grow to $9 \mathrm{~mm}$ (Dickinson, 1982) and $4.1 \mathrm{~mm}$, respectively, in length (Williams, 1984). The larger specimens of $R$. agassizii, which are larger than $P$. extenta, fed also on larger prey (fish, crabs and penaeidean shrimps). The diet shift according to the size of the skate and the importance of amphipods for juveniles have been observed by many researchers (McEachran et al., 1976; Du Buit, 1972; Queiroz, 1986).

From results of the cluster analysis associated with the first maturity length, it seems that the diet shift is associated with the size of the skate rather than with its sexual maturity. This pattern was more evident for R. agassizii.

At first, $P$. glansdisiimilis seems to display an ontogenetic shift in its diet, changing from amphipods to carideans, as the skate grows. However, as data is on the total sample, regardless of the season, this result relates to the consumption of carideans by adults during winter, when no juveniles were captured. 
A diet shift pattern during the life cycle is observed in many teleosts (Keast, 1977; Blaber \& Bulman, 1987) as much as in the elasmobranchs (Ajayi, 1982; Sedberry, 1983; Cunha et al., 1986) and constitutes a strategy for intraspecific resource partitioning in fish assemblages. On the whole, amphipods were more important for juveniles and fish for adults of $R$. agassizii, which is similar to the result observed for Raja clavata, $R$. montagui, R. microocellata (Steven, apud Ajayi, 1982) and $R$. miraletus (Ezzat et al., 1987). Juveniles of these species feed on small crustaceans and adults on fish.

However, seasonality can influence the degree of diet overlap between juveniles and adults, as
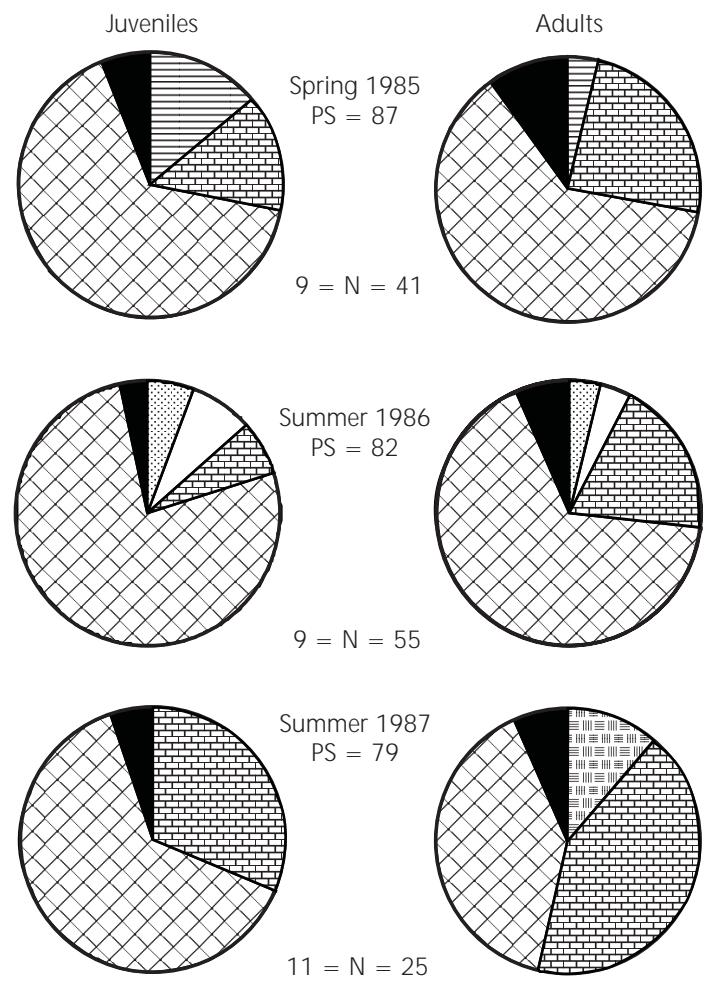

\begin{tabular}{|c|c|c|}
\hline 目Unid. crustaceans & 栕 Unid. decapods & 0 Unid. shrimps \\
\hline$\square$ Caridea & 四Brachyura & 囚 Amphipoda \\
\hline
\end{tabular}

Fig. 11 - Index of Relative Importance (IRI\%) of prey items consumed by juveniles and adults of P. extenta, by season (PS $=$ Percentage of Similarity, $\mathrm{N}=$ number of stomachs analyzed). verified for $R$. agassizii when caridean shrimps seems to be more abundant.

This is closely in line with the statement that higher diet overlaping between age classes occurs during prey abundance peaks (Keast, 1977).

Juveniles and adults of $P$. extenta presented a very similar diet during spring 1985-86 and summer 1987 due to the consumption of amphipods, brachyurans and carideans. In the other seasons, juveniles of this species were absent.

Inter and intraspecific comparisons showed that juveniles of $R$. agassizii presented higher feeding similarity with juveniles of $P$. extenta than with adults of their own species, while diets of juveniles and adults of $P$. extenta were very similar.
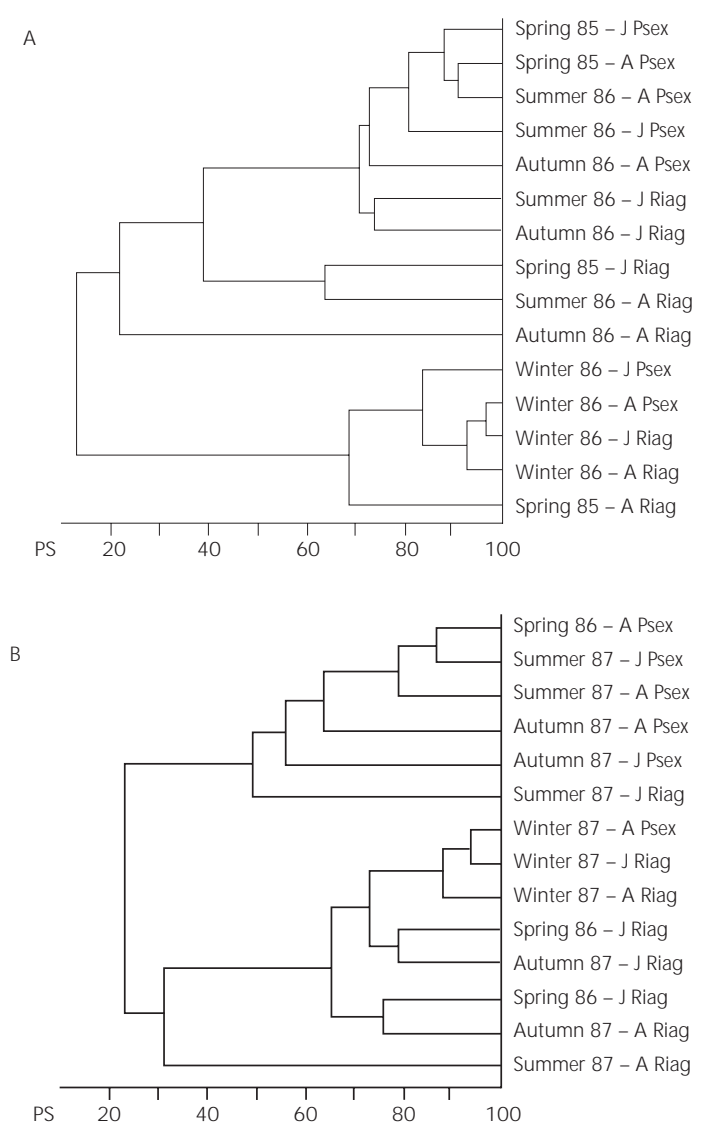

Fig. 12 - Dendogram showing the seasonal feeding similarity among juveniles and adults of $R$. agassizii and $P$. extenta in the first (A) and second (B) year of sampling. 
The low intraspecific feeding overlap verified in $R$. agassizii must be related to the greater ability of adults in the consumption of a broader range of prey, due to their size. Larger predators may exploit a broader range of prey size, and food diversity in terms of types of prey or species, may be higher in larger animals (Schoener, 1971).

The absence of juveniles of $P$. extenta during autumn and winter might be associated with the high inter and intraspecific feeding overlap, which may be leading this group to spatial segregation.

The low diet overlap between the two skates during most of the year, is partially to be explained by their differential distribution, since $P$. extenta occurred around the $50 \mathrm{~m}$ isobath, while $R$. agassizii occurred in the shallower area.

Higher diet overlap, as well as spatial overlap, occurred during both winters, when the skates fed mainly on L. serratorbita.

The exploitation of the same resource in these periods seems to be related to the availability and abundance peaks of this shrimp, that allows food sharing, associated with the decrease in the abundance of amphipods, the main prey of $P$. extenta in the other seasons.

Food sharing in conditions of high abundance of prey has been corroborated by many workers (McEachran et al., 1976; Ross, 1978; Tyler, 1972).

This strategy of resource utilization showed the species's interactions, as well as their abiotic interactions over the year.

Acknowledgments - This work was part of Elizabeti Y. Muto's Master's thesis, supported by Capes (Coordenadoria de Aperfeiçoamento de Pessoal de Ensino Superior). Dr. Lucy S. H. Soares was partially supported by grant n. 523249/96-9 of the CNPq (Conselho Nacional de Pesquisa). The authors are grateful to the CIRM (Comissão Interministerial para Recursos do Mar) for providing financial support for the undertaking of the research. Our gratitude to Dr. Paulo César Paiva and MSc Emilia Arasaki for their respective identification of polychaetes and crustaceans. We also thank the three anonymous reviewers for reading the manuscript and providing valuable suggestions and Eloci Peres Rios for reviewing the text in English.

\section{REFERENCES}

ABD EL-AZIZ, S. H., 1986, Food and feeding habits of Raja species (Batoidea) in the Mediterranean waters of Alexandria. Bull. Inst. Oceanogr. Fish., Arab. Repub. Egypt, 12: 265-276.
AJAYI, T. O., 1982, Food and feeding habits of Raja species (Batoidei) in Carmarthen Bay, Bristol Channel. J. mar. Biol. Ass. U. K., 62: 215-223.

BACESCU, M. \& QUEIROZ, E. L., 1985, The contribution of Cumacea in the feeding of the Rajidae Sympterygia acuta and Sympterygia bonapartei from Rio Grande do Sul - S. Brazil. Trav. Mus. Hist. Nat. Gr. Antipa, 27: 7-18.

BERESTOVSKIY, E. G., 1989, Feeding in the skates, Raja radiata and Raja fyllae, in the Barents and Norwegian Seas. J. Ichthyol., 29: 88-96.

BERG, J., 1979, Discussion of methods of investigation the food of fishes, with reference to a preliminary study of the prey Gobiusculus flavescens (Gobiidae). Mar. Biol., 50: 263-273.

BLABER, S. J. M. \& BULMAN, C. M., 1987, Diets of fishes of the upper continental slope of eastern Tasmania: content, calorific values, dietary overlap and trophic relationships. Mar. Biol., 95: 345-356.

BOWEN, S. H., 1983, Quantitative description of the diet. In: L. A. Nielsen \& D. L. Johnson (eds.), Fishery Techniques. American Fishery Society, Maryland, pp. 325-336.

CARVAlHO, M. R. de \& FIGUEIREDO, J. L. de, 1994, Psammobatis extenta (Garman, 1913): A Senior Synonym of Psammobatis glansdissimilis McEachran, 1983 (Chondrichthyes, Rajidae). Copeia, 4: 1029-1033.

CASTRO FILHO, B. M., MIRANDA, L. B. de \& MIYAO, S. Y., 1987, Condições hidrográficas na plataforma continental ao largo de Ubatuba: variações sazonais e em média escala. Bolm Inst. Oceanogr., 35: 135-151.

CUNHA, P., CAlvário, J., MARQUES, J. C. \& RÉ, P., 1986, Estudo comparativo de Raja brachyura Lafont, 1983, Raja clavata Linné, 1758, Raja montagui Fowler, 1910 e Raja naevus Muller \& Henle, 1841 (Pisces: Rajidae) da costa portuguesa. Arq. Mus. Boc., 3: 137154.

DICKINSON, J. J., 1982, The systematics and distributional ecology of the family Ampeliscidae (Amphipoda: Gammaridea) in the Northeastern Pacific region. I. The genus Ampelisca. Biol. Oceanogr., 10: 1-39.

DU BUIT, M. H., 1972, Rôles des facteurs géographiques saisonniers dans l'alimentation de $R$. naevus e $R$. fullonica. Trav. Lab. Biol. Halieutique, 6: 33-50.

EZZAT, A., ABD EL-AZIZ, S. H., EL-GHARABAWY, M. M. \& HUSSEIN, M. O., 1987, The food of Raja miraletus Linnaeus, 1758, in mediterranean waters off Alexandria. Bull. Inst. Oceanogr. Fish., Arab. Repub. Egypt, 13: 5974.

FAUCHALD, K. \& JUMARS, P. A., 1979, The diet of worms: a study of polychaete feeding guilds. Oceanogr. Mar. Biol. Ann. Rev., 17: 193-284.

FIGUEIREDO, J. L., 1981, Estudo da distribuição endêmica de peixes da Província Zoogeográfica Marinha Argentina. Tese de Doutorado, Instituto de Biociências, USP, 121p. 
GOUVÊIA, E. P. de \& QUEIROZ, E. L., 1988, Braquiúros (Crustacea: Decapoda) utilizados na alimentação de peixes Rajidae no litoral sul do Brasil. Ciênc. Cult., 40: 276-279.

GREENSTREET, S. P. R., 1995, Estimation of the daily consumption of food by fish in the North Sea in each quarter of the year. Rpt Scot. Fish. Res. (55): 16p.

GRIFFITHS, D., 1975, Prey availability and the food of predators. Ecology, 56: 1209-1214.

HYSLOP, E. J., 1980, Stomach contents analysis, a review of methods and their application. J. Fish Biol., 17: 411-429.

JONES, R., 1982, Ecosystems, food chain and fish yields. In: D. Pauly \& G. I. Murphy (eds.), Theory and management of tropical fisheries. ICLARM Conf. Proc., 9: 195-239.

KEAST, A., 1977, Diets overlap and feeding relationships between the year classes in the yellow perch (Perca flavescens). Environ. Biol. Fishes, 2: 53-70.

KERR, S. R., 1971, Prediction of fish growth efficiency in nature. J. Fish. Res. Bd Can., 28: 809-814.

LINTON, L. R., DAVIES, R. W. \& WRONA, F. J., 1981, Resource utilization indices: an assessment. J. Anim. Ecol. 50: 283-292.

LIVINGSTON, P. A., DWYER, D. A., WENCKER, D. L., YANG, M. S. \& LANG, G. M., 1986, Trophic interactions of key fish species in the Eastern Bering Sea. Inst. North. Pacif. Fish. Com. Bull., 47: 49-65.

MATSUURA, Y., 1986, Contribuição ao estudo da estrutura oceanográfica da região Sudeste entre Cabo Frio (RJ) e Cabo de Santa Marta (SC). Ciênc. Cult., São Paulo, 38: 1439-1450.

McEACHRAN, J. D., BOESCH, D. F. \& MUSICK, J. A., 1976, Food division within two sympatric species-pairs of skates (Pisces: Rajidae). Mar. Biol., 35: 301-317.

McEACHRAN, J. D. \& DUNN, K. A., 1998, Phylogenetic analysis of skates, a morphologically consevative clade of Elasmobranchs (Chondrichthyes: Rajidae). Copeia, (2): 271-290.

MILLS, E. L., 1967, The biology of an ampeliscid amphipod crustacean sibling species pair. J. Fish. Res. Bd Can., 24: 305-355.

MOYLE, P. B. \& CECH-JR, J. J., 1988, Fishes: an introduction to ichthyology. $2^{\text {nd }}$ ed., Prentice Hall, New Jersey, $559 \mathrm{p}$.

NIKOLSKI, G. V., 1963, The ecology of fishes. Academic Press, London, 352p.

PEDERSEN, S. A., 1995, Feeding habits of starry ray (Raja radiata) in the West Greenland waters. ICES J. Mar. Science, 52: 43-53.

PETTI, M. A. V., 1990, Hábitos alimentares dos crustáceos decápodos braquiúros e seu papel na rede trófica do infralitoral de Ubatuba (litoral norte do Estado de São Paulo, Brasil). Dissertação de Mestrado, Instituto Oceanográfico, USP, 150p.
PILLAY, T. V. R., 1952, A critique of the methods of study of fishes. J. Zool. Soc. India, 4: 185-200.

PINKAS, L., OLIPHANT, M. S. \& IVERSON, I. L. K., 1971, Food habits of albacore, bluefin tuna and bonito in Californian waters. Fish Bull. Calif. Fish Game, 152: 1-105.

PIRES, A. M. S., 1987, Contribution of isopods in the feeding of Sympterygia spp. (Pisces: Rajidae) with a description of Ancinus gaucho sp.n. (Isopoda: Sphaeromatidae). Bolm Inst. Oceanogr., 35(2): 115-122.

PIRES, A. M. S., 1992, Structure and dynamics of benthic megafauna on the continental shelf offshore of Ubatuba, southeastern Brazil. Mar. Ecol. Prog. Ser., 86: 63-76.

PIRES-VANIN, A. M. S., 1993, A macrofauna bêntica da plataforma continental ao largo de Ubatuba, São Paulo, Brasil. Publção Esp. Inst. Oceanogr., São Paulo (10): 137158.

QUEIROZ, E. L., 1986, Estudo comparativo da alimentação de Sympterygia acuta Garman, 1877 e S. bonapartei Müller \& Henle, 1841 (Pisces: Rajiformes) com relação a: distribuição, abundância, morfologia e reprodução, nas águas litorâneas do Rio Grande do Sul. Dissertação de Mestrado, FURG, 326p.

RASCHI, W. \& ADAMS, W. H., 1988, Depth-related modifications in the eletroreceptive system of the eurybathic skate, Raja radiata (Chondrichthyes: Rajidae). Copeia, 1: 116-123.

RIOS, M. A. T., 1994, Alimentação dos Sciaenidae Ctenosciaena gracilicirrhus, Cynoscion jamaicensis, Cynoscion guatucupa $e$ Paralonchurus brasiliensis, da região costeira de Ubatuba, São Paulo, Brasil. Dissertação de Mestrado, Instituto Oceanográfico, USP, 138p.

ROCHA, G. R. A. \& ROSSI-WONGTSCHOWSKI, C. L. D. B., 1998, Demersal Fish Community of the inner shelf of Ubatuba, South-eastern Brazil. Rev. Brasil. Oceanogr., 46(2): 93-109.

ROSS, S. T., 1978, Trophic ontogeny of the leopard searobin, Prionotus punctatus scitulus (Pisces: Triglidae). Fish. Bull., 76: 225-234.

SARTOR, S. M., 1989, Composição e distribuição dos Brachyura (Crustacea: Decapoda), no litoral norte do Estado de São Paulo. Tese de Doutorado, Instituto Oceanográfico, USP, 197p.

SEDBERRY, G. R., 1983, Food habits and trophic relationships of a community of fishes on the outer continental shelf. NOAA Tech. Rep. NMFS SSRF-U.S.-773, 1-56.

SHOENER, T. W., 1971, Theory of feeding strategies. Ann. Rev. Ecol. Syst., 2: 369-404.

SNEATH, P. H. A. \& SOKAL, R. R., 1973, Numerical Taxonomy. W. H. Freeman and Company, San Francisco, 573p.

SOARES, L. S. H., ROSSI-WONGTSCHOWSKI, C. L. D. B., ALVARES, L. M. C., MUTO, E. Y. \& GASALLA, M. A., 1992, Grupos tróficos de peixes demersais da plataforma continental interna de Ubatuba, Brasil. I. Chondrichthyes. Bolm Inst. Oceanogr., 40: 79-85. 
SOARES, L. S. H., VAZZOLER, A. E. A. de M. \& CORREA, A. R., 1999, Diel feeding chronology of the skate Raja agassizii (Müller \& Henle, 1841) (Pisces: Elasmobranchii) on the Continental Shelf of Ubatuba, Southeastern Brazil. Rev. Brasil. Zool., 16(1): 201-212.

TYLER, A. V., 1972, Food resource division among northern, marine, demersal fishes. J. Fish. Res. Bd Can., 29: 9971003.

VALÉRIO-BERARDO, M. T., 1992, Composição e distribuição de Amphipoda de fundos não consolidados da região de Ubatuba (SP, Brasil). Tese de Doutorado, Instituto Oceanográfico, USP, 148p.
WERNER, E. E. \& HALL, D. J., 1974, Optimal foraging and the size selection of prey by the bluegill sunfish (Lepomis macrochirus). Ecology, 55: 1042-1052.

WILLIANS, A. B., 1984, Shrimps, lobsters and crabs of the Atlantic coast of the eastern United States, Maine to Florida. Smithsonian Institution Press, Washington, D.C., $550 \mathrm{p}$. 